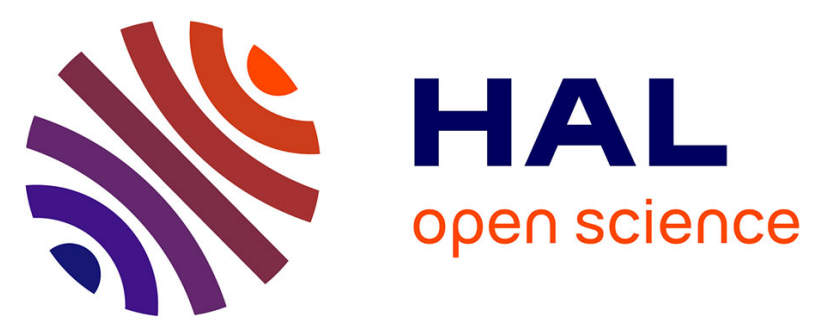

\title{
Occurrence of mycotoxins in cassava (Manihot esculenta Crantz) and its products
}

Yann Adjovi, B. J. G. Gnonlonfin, Sylviane Bally, Jean-Denis Bailly, Souria Tadrist, Olivier Puel, Isabelle P. Oswald, A. Sanni

\section{- To cite this version:}

Yann Adjovi, B. J. G. Gnonlonfin, Sylviane Bally, Jean-Denis Bailly, Souria Tadrist, et al.. Occurrence of mycotoxins in cassava (Manihot esculenta Crantz) and its products. International Journal of Food Safety, Nutrition and Public Health, 2015, 5, pp.217-247. 10.1504/IJFSNPH.2015.070157 . hal01594243

\section{HAL Id: hal-01594243 \\ https://hal.science/hal-01594243}

Submitted on 26 Sep 2017

HAL is a multi-disciplinary open access archive for the deposit and dissemination of scientific research documents, whether they are published or not. The documents may come from teaching and research institutions in France or abroad, or from public or private research centers.
L'archive ouverte pluridisciplinaire HAL, est destinée au dépôt et à la diffusion de documents scientifiques de niveau recherche, publiés ou non, émanant des établissements d'enseignement et de recherche français ou étrangers, des laboratoires publics ou privés.

\section{(C)(1) (2)}

Distributed under a Creative Commons Attribution - ShareAlikel 4.0 International 


\title{
Occurrence of mycotoxins in cassava (Manihot esculenta Crantz) and its products
}

\author{
Yann C.S. Adjovi* \\ Research Centre in Food Toxicology, \\ INRA, UMR1331, Toxalim, \\ F-31027 Toulouse, France \\ and \\ Universite de Toulouse III, \\ INP, Toxalim, F-31076 Toulouse, France \\ and \\ Laboratoire de Biochimie et de Biologie Moleculaire, \\ 04, P.O. Box 0320, Cotonou, Benin, Africa \\ Email: yann.adjovi6@gmail.com \\ *Corresponding author

\section{Benoit J.G. Gnonlonfin} \\ Biosciences, Eastern and Central Africa, \\ International Livestock Research Institute, \\ 12, P.O. Box 30709, Old Naivasha Road, Nairobi, Kenya \\ Email: bgnonlonfin@yahoo.fr
}

\section{Sylviane Bailly, Jean-Denis Bailly, Soraya Tadrist, Olivier Puel and Isabelle P. Oswald}

\author{
Research Centre in Food Toxicology, \\ INRA, UMR1331, Toxalim, \\ F-31027 Toulouse, France \\ and \\ Universite de Toulouse III, \\ ENVT, INP, Toxalim, F-31076 Toulouse, France \\ Email: s.bailly@envt.fr \\ Email: jd.bailly@envt.fr \\ Email: souria.tadrist@toulouse.inra.fr \\ Email: Olivier.Puel@toulouse.inra.fr \\ Email: ioswald@toulouse.inra.fr
}

\section{Ambaliou Sanni}

Laboratoire de Biochimie et de Biologie Moleculaire, 04, P.O. Box 0320, Cotonou, Benin, Africa

Email: ambaliou.sanni@gmail.com 
Abstract: Contamination of foods with mycotoxins represents an important limit to the income of farmers and a major public health concern especially in tropical countries. Cassava represents an important part of the diet of many people in this part of the word and the most important smallholder crop in Africa. Fungal contamination of cassava products can occur at pre-harvest level or after, during processing, according to the conditions (moisture, temperature, competition with other microorganisms). Such fungal contamination can also lead to mycotoxin accumulation. The most common fungi found in cassava products belong to genera Rhyzopus, Aspergillus, Fusarium, Phoma and Penicillium. Their corresponding mycotoxins could also be found in cassava. However, until now, the correlation between the presence of Aspergillus flavus and its toxins aflatoxins remains unclear. In this review, we broadly report data about mycotoxins contamination of cassava (Manihot esculenta Crantz) and its derivatives, with a special emphasis on aflatoxins.

Keywords: cassava; mycotoxin; aflatoxins; tropical region.

Reference to this paper should be made as follows: Adjovi, Y.C.S., Gnonlonfin, B.J.G., Bailly, S., Bailly, J-D., Tadrist, S., Puel, O., Oswald, I.P. and Sanni, A. (2015) 'Occurrence of mycotoxins in cassava (Manihot esculenta Crantz) and its products', Int. J. Food Safety, Nutrition and Public Health, Vol. 5, Nos. 3/4, pp.217-247.

Biographical notes: Yann C.S. Adjovi is a Research Assistant, $\mathrm{PhD}$ and specialist of biochemistry and molecular biology applied to food security.

Benoit J.G. Gnonlonfin is a $\mathrm{PhD}$ and specialist of sampling strategy and aflatoxin analysis.

Sylviane Bailly is a DVM and specialist of fungal eco-physioloy and morphological analysis.

Jean-Denis Bailly is a DVM, PhD, and Professor in Food Hygiene at the National Veterinary School of Toulouse.

Soraya Tadrist is a technician and specialist in purification of fungal metabolites and mycotoxin analysis.

Olivier Puel is a research engineer, $\mathrm{PhD}$ and specialist of molecular analysis of mycotoxin biosynthesis and fungal metabolome.

Isabelle $\mathrm{P}$. Oswald is an agronomist, $\mathrm{PhD}$ and specialist of mycotoxin toxicity and on their impact on immune function. She is the leader of the team Biosynthesis and Toxicity of Mycotoxins within Toxalim unit.

Ambaliou Sanni is a biochemist and molecular biologist, Professor, head of Biochemistry and Molecular Biology unit and head of $\mathrm{PhD}$ School in University of Abomey-Calavi (Benin). 


\section{Introduction}

Mycotoxins are toxic secondary metabolites of filamentous micromycetes. Exposure to mycotoxins can lead to both acute and chronic toxicities ranging from death to deleterious effects on the central nervous, cardiovascular, pulmonary and digestive systems. Mycotoxins may also be carcinogenic, mutagenic, teratogenic and immunosuppressive (FAO, 2001). Some, such as aflatoxin B1, also have synergistic effect with the hepatitis B virus in the etiology of liver cancer and probably interact with HIV/AIDS (Williams et al., 2004).

Problems caused by mycotoxins have consequences on trades and economy. On domestic and international markets, economic losses due to the existence of regulations occur at various levels along the processing chain, from the producers to the commodity brokers, processors and the animal producers (FAO, 2004).

Different foods such as cereals, spices and dried crops can be contaminated by mycotoxins. Cereal products (corn and wheat), peanuts, cottonseeds and mixed feeds appeared to be the most commonly contaminated foodstuffs. In tropical areas, aflatoxins could be found at high levels in several crops such as maize [30-920 $\mathrm{ag} / \mathrm{kg}$ (Rustom, 1997) and $24 \mathrm{ag} / \mathrm{kg}$ in 2006 in Kenya (Johnni et al., 2011)] but also in dried fish, dried chili peppers, corn and peanuts in Thailand, at levels of 772, 996, 2,700, and over $12,000 \wedge \mathrm{g} / \mathrm{kg}$, respectively (Shank et al., 1972). In temperate areas, the most common mycotoxins are deoxynivalenol (DON) and its derivatives found in cereal grains and animal feeds, fumonisins that are frequent contaminants of maize, zearalenone (ZEA) in the cereals and silage. These three kind of toxins are produced in the fields, before harvest of grains. Patulin can also contaminate apple and its derivates (Marczuk et al., 2012).

Within this context, the quality and safety of agricultural products and food are surveyed to limit consumer exposure.

Cassava (Manihot esculanta Crantz) is the staple food and source of nourishment for more than one billion people worldwide (FAO, 2011) especially in Africa, Asia and South America. Because of its high water contain, cassava must be transformed into various derivatives to ensure its availability outside harvest periods and to reduce post-harvest losses. The cassava products can be fermented, dried or roasted, and the most common form is chips. This product serves as food for both human and animals and can be maintained up to one year (Wareing et al., 2001).

However, tropical climate of some geographical areas of cassava production may contribute to fungal development of many species and subsequent toxinogenesis on such raw material (Bankole and Adebanjo, 2003). Moreover, the processing conditions and storage premises are not always well adapted to protect cassava products from secondary contamination and/or fungal development.

Considering the importance of this crop in developing countries and subsequent possible fungal toxin production, various studies have attempted to evaluate cassava products contamination with moulds and mycotoxins. A number of potentially mycotoxigenic fungi have been isolated from cassava products and mycotoxins contamination of cassava has been documented but the potential sanitary risk of such contamination was not fully assessed (Westby, 2002).

The goal of this review is to report the available data regarding the contamination of cassava products by moulds and mycotoxins. 


\section{Mycotoxins and toxinogenic fungi}

\subsection{Definition and health impacts}

Mycotoxins are highly toxic substances. They can contaminate agricultural commodities before or after harvest (Cole et al., 2003). Their presence in foods and feeds is linked to cancers, immune system defects, growth retardations, liver diseases and death. Adverse effects of mycotoxins poisoning have been well documented over the years ( $\mathrm{Wu}, 2004)$. The presence of mycotoxins also limits incomes of farmers due to existing export trade restrictions. Factors that contribute to mycotoxins contamination of foods and feeds are mainly related to environmental conditions and especially humidity and temperatures that may favour fungal proliferation and toxinogenesis.

\subsection{Toxinogenic species}

Mycotoxins are secondary metabolites of fungi that are microorganisms lacking chlorophyll production and depend on substrate to grow. They may act as saprophytes that breakdown non-living organic materials and transport available nutrients to the growing hyphae or parasites attacking and exhibiting pathogenic effect on both plants and animals (Adaku et al., 2012). Fungi have a worldwide distribution, and are able to grow in a wide type of environments, including deserts, hyper saline environments (Sancho et al., 2007), deep sea (Hawksworth, 2006), rocks (Mueller and Schmit, 2006), and under a broad range of conditions such as extremely low and high temperatures. They have been shown to be able to survive to intense ultra violet and cosmic radiations encountered during space travel (Alexopoulos et al., 1996).

Many fungi are pathogens of plants, while a smaller number are pathogenic for animals, including human beings. They attack and destroy raw and manufactured products for post-harvested steps resulting in great economic losses (Atanda et al., 2011).

Food fungi were classified into three groups namely: field, storage and advanced decay fungi.

Field fungi invade developing and mature seeds before harvest. They include species belonging to Alternaria, Fusarium, Helminthosporium, Cladosporium, Chaetomium and Curvularia genera by decreasing order of predominance (Jarvis, 1971; Magro et al., 2010). All field fungi require high moisture content between $20 \%$ to $25 \%$ to grow and are therefore referred as hygrophilic fungi (Jesenska et al., 1993; Magro et al., 2010). The same authors gave the representative species of field fungi as Alternaria alternata, Cladosporium herbarum, Fusarium graminearum, Rhizppus nigricans and Trichoderma lignorum. The latest is ranked in the top 10 of plant pathogens in the world (Dean et al., 2012).

The fungi that invade grains after harvest and during storage mainly belong to Aspergillus, Penicillium, Phoma, Sporendonema genera and some species of Fusarium (Jarvis, 1971; Elegbede, 1978; Rasch et al., 2010; Magro et al, 2010). They are able to grow on substrates in which the moisture content has been reduced to $13 \%$ to $18 \%$, equivalent to an equilibrium relative humidity of $70 \%$ to $85 \%$ (Jarvis, 1971; Codex Alimentarius, 2012). This group, known as mesophilic storage fungi, has the following representative species: Aspergillus flavus, A. fumigatus, A. terreus, Paecilomyces varioti, Penicillium aurantiogriseum, P. citrinum and P. viridicatum. Others are Aspergillus ochraceus and A. versicolor (Lillehoj, 1973; Codex Alimentarius, 2012). The main 
factors influencing their development are moisture content in stored food, temperature, storage length, degree of invasion before arrival at the storage site, amount of foreign material and insects and mites activities (Ominski et al., 1994; Codex Alimentarius, 2012). According to fungal physiology, mycotoxins contamination may start in fields, and ultimately cuts across the value chain, affecting farm families, traders, markets and finally, consumers. There are more than 400 mycotoxins produced by a plethora of fungi. Toxin profiles differ across crops, countries and regions within countries (Cole et al., 2003). Among the fungal genera, Fusarium, Aspergillus and Penicillium are considered as the most important because of their ability to produce mycotoxins such as fumonisin (FB), aflatoxin (AF), ochratoxin (OTA), ZEA and trichothecenes (DON, T-2 toxin, nivalenol) (Adaku et al., 2012). Table 1 shows major mycotoxins and their producers.

Table 1 Mycotoxins, fungi and toxicity

\begin{tabular}{|c|c|c|c|}
\hline Mycotoxins & Fungal species & Toxicity & References \\
\hline Aflatoxins & $\begin{array}{c}\text { Aspergillus section Flavi: } \\
\text { A. flavus; } \\
\text { A. parasiticus }\end{array}$ & $\begin{array}{l}\text { Hepatotoxic, Carcinogenic, and } \\
\text { other harmful effects to human, } \\
\text { poultry, pigs and cattle can be } \\
\text { noticed. }\end{array}$ & Wu (2004) \\
\hline Citrinin & $\begin{array}{c}\text { Penicillium citrinum; } \\
\text { P. expansum }\end{array}$ & Nephrotoxic & $\begin{array}{l}\text { Peraica et al. } \\
\quad(1999)\end{array}$ \\
\hline $\begin{array}{l}\text { Cyclopiazonic } \\
\text { acid }\end{array}$ & $\begin{array}{c}\text { Penicillium cyclopium, } \\
\text { Peniccillium camemberti } \\
\text { Aspergillus flavus }\end{array}$ & $\begin{array}{l}\text { Induces hyperemia and } \\
\text { ulceration of proventriculus; } \\
\text { focal necrosis in the liver and } \\
\text { spleen; increased weight of } \\
\text { pancreas and kidney. }\end{array}$ & $\begin{array}{l}\text { Dorner et al. } \\
\text { (1983), Gentles } \\
\text { et al. (1999) }\end{array}$ \\
\hline Deoxynivalenol & $\begin{array}{l}\text { Fusarium graminearum; } \\
\text { F. culmorum }\end{array}$ & $\begin{array}{l}\text { Provokes barley acute human } \\
\text { toxicosis, internal disturbances, } \\
\text { growth inhibition in pigs. }\end{array}$ & Pestka (2008) \\
\hline $\begin{array}{l}\text { Diacetoxyscirpe } \\
\text { nol }\end{array}$ & $\begin{array}{l}\text { Fusarium } \\
\text { sporotrichioides; } \\
\text { F. poae }\end{array}$ & $\begin{array}{l}\text { Provokes ill-thrift, decrease } \\
\text { feed consumption, slow } \\
\text { growth, diarrhea and abortion. }\end{array}$ & $\begin{array}{l}\text { Pronk et al. } \\
\quad(2002)\end{array}$ \\
\hline Ergot alkaloids & Claviceps purpurea & $\begin{array}{c}\text { Responsible for } \\
\text { vasoconstriction, neural } \\
\text { disorders, skin necrosis and } \\
\text { agalactia. }\end{array}$ & $\begin{array}{l}\text { Dyer (1993), } \\
\text { Cross (2003) }\end{array}$ \\
\hline Fumonisins & $\begin{array}{c}\text { Fusarium moniliforme; } F \text {. } \\
\text { verticillioides; } \\
\text { F. proliferatum }\end{array}$ & $\begin{array}{c}\text { Suspected to cause esophageal } \\
\text { cancer in human pulmonary } \\
\text { edema in pigs and } \\
\text { leukoencephalomalacia } \\
\text { inequines. }\end{array}$ & Marasas (2001) \\
\hline Ochratoxin A & $\begin{array}{c}\text { A. ochraceus; } \\
\text { A. carbonarius; } \\
\text { Penicillium verrucosum }\end{array}$ & $\begin{array}{l}\text { May be carcinogenic, kidney } \\
\text { damage and other harmful } \\
\text { effects in pigs and poultry. }\end{array}$ & $\begin{array}{l}\text { Gentles et al. } \\
\text { (1993) }\end{array}$ \\
\hline Patulin & $\begin{array}{l}\text { P. expansum; } \\
\text { A. clavatus }\end{array}$ & $\begin{array}{l}\text { Neurotoxic; responsible for } \\
\text { haemorrhages of lung and } \\
\text { brain. }\end{array}$ & $\begin{array}{l}\text { Peraica et al. } \\
\quad(1999)\end{array}$ \\
\hline
\end{tabular}

Notes: The most dangerous mycotoxin is aflatoxin B1 and the principal producer is Aspergillus flavus. The toxicity of other mycotoxins is tested in animals and its consequences on human health are studying. 
Table 1 Mycotoxins, fungi and toxicity (continued)

\begin{tabular}{|c|c|c|c|}
\hline Mycotoxins & Fungal species & Toxicity & References \\
\hline Peniccillic acid & Peniccilium viridicatum & $\begin{array}{l}\text { Toxic to kidneys and liver; can } \\
\text { cause abortion; reduces growth } \\
\text { rate and immunity. }\end{array}$ & $\begin{array}{l}\text { Pandiyan et al. } \\
\text { (1990), Bernhoft } \\
\text { et al. (2004), } \\
\text { Keblys et al. } \\
\text { (2004) }\end{array}$ \\
\hline sterigmatocystin & $\begin{array}{c}\text { Aspergillus } \\
\text { nidulanellusnidulellus, } A . \\
\text { glaucus, } \text {. sydowii, } A . \\
\text { versicolor }\end{array}$ & $\begin{array}{c}\text { Carcinogenic (group 2B), } \\
\text { hepatotoxic; causes toxemia. }\end{array}$ & $\begin{array}{l}\text { IARC (1987), } \\
\text { Sun et al. (2002) }\end{array}$ \\
\hline $\mathrm{T}-2$ toxin & $\begin{array}{l}\text { Fusarium } \\
\text { sporotrichioides; } \\
\text { F. poae }\end{array}$ & $\begin{array}{l}\text { Alimentary aleucy toxic; } \\
\text { reduces inflammatory response } \\
\text { and inhibits protein DNA, } \\
\text { RNA synthesis in poultry. }\end{array}$ & $\begin{array}{l}\text { Sokolovic et al. } \\
\text { (2008) }\end{array}$ \\
\hline Tenuazonic acid & Alternaria alternata & $\begin{array}{l}\text { Causes hematological disorder } \\
\text { in human (onyaalai); collapse } \\
\text { in cardiovascular system, } \\
\text { dysplasia, nausea in mouse and } \\
\text { rat. }\end{array}$ & $\begin{array}{l}\text { Steyn and Rabier } \\
\text { (1976), Zhou and } \\
\text { Qiang (2008) }\end{array}$ \\
\hline Zearalenone & $\begin{array}{l}\text { Fusarium. culmorum; } \\
\text { F. graminearum }\end{array}$ & $\begin{array}{l}\text { Estrogenic toxin causes } \\
\text { infertility in animals; }\end{array}$ & JECFA (2001) \\
\hline
\end{tabular}

Notes: The most dangerous mycotoxin is aflatoxin $\mathrm{B} 1$ and the principal producer is Aspergillus flavus. The toxicity of other mycotoxins is tested in animals and its consequences on human health are studying.

\subsection{Human and animals toxicity with regulatory consequences}

Mycotoxins concerns have grown during the last few decades because of their implications in human and animal health, productivity, and the cost of their management for trades.

This has significant consequences in both developed and developing countries. Worldwide, the primary concern with mycotoxins contamination of the food supply chain is human health (Shier et al., 2005; Wild, 2007; Shephard, 2008b; Bryden, 2012) followed by the impact on animal health and production (Shier et al., 2005).

\subsubsection{Human toxicity}

The implications of ingestion or absorption of mycotoxins on human health include immunosuppression, impaired growth, various cancers and death depending on the type, the period of exposure and the amount of toxins ingested. Moreover, a synergistic effect between mycotoxins exposure and some important diseases in the African continent such as malaria, kwashiorkor, hepatitis B and HIV/AIDS have been suggested (Williams et al., 2004; Wagacha and Muthomi, 2008). The most toxic and dangerous mycotoxins are aflatoxins. Indeed, aflatoxin B1 (AFB1) is the most potent hepatic carcinogen known in mammals and has been classified by the International Agency for Cancer Research in the group I of molecules that are carcinogenic for both human and animals (IARC, 1993). AFB1 also displays immunosuppressive properties (Meissonnier et al., 2008) and is involved in growth impairment observed in children (Gong et al., 2004; Khlangwiset 
et al., 2011). Exposure to aflatoxin in Sub-Saharan Africa is very frequent. In some areas, $99 \%$ of tested children display aflatoxin residues in their blood (Gong et al., 2002) and this high exposure contributes to appearance of chronic hepatomegaly in children (Gong et al., 2012). Contamination of food by very high levels of aflatoxin can also lead to fatal consequences such as the death of 125 people in Kenya (Lewis et al., 2005; Probst et al., 2007).

Some studies on fumonisins, that appear to be the second most important mycotoxin family in tropical countries, have found their major role in the etiology of human oesophageal cancers in regions where this ailment is abnormally highly prevalent. A role in neurological diseases in human population can also be probably considered. Due to the structural similarity between fumonisins and sphingosine which is a principal constituent of cell membranes, fumonisins are the first known naturally occurring inhibitors of sphingolipid biosynthesis (Gamal et al., 2012).

\subsubsection{Animal toxicity}

Mycotoxin-contaminated feeds reduce animal growth, productivity and may lead to death. AFB1 is the most toxic aflatoxin, followed in decreasing order by AFM1, AFG1 and AFB2 to AFG2. The toxicity of aflatoxin G1, G2 and B2 are respectively $50 \%, 80 \%$ and $90 \%$. In animals, AFB1 causes liver necrosis at centro-lobular level.

The effects of aflatoxins on animal health vary according to the species. Animals such as veals, chicken, duckling, guinea pigs and porks are sensitive to AFB1 whereas goats, sheeps, rats and mices are relatively resistant (Patterson and Allcroft, 1970). Among birds, the susceptibility varies according to the species. In turkeys, the disease known as 'Turkey X disease' resulted in the death of 20,000 turkeys after renal dilatation and congestion in England in 1960 (Stevens et al., 1960). Cats are particularly sensitive, with death occurring between 48 and 72 hours. This sensitivity is also noted in ducklings when exposed to AFB1 with a LD50 of $0.56 \mathrm{mg} / \mathrm{kg}$. There may be a reduction in income from poultry, pigs and cattle as a result of death due to either carcinogenesis or aflatoxicosis by aflatoxin B1 (Nyathi et al., 1987).

In Africa, the second most common mycotoxin is fumonisin B1. The prevalence of fumonisins has been reported to be $100 \%$ or close to it in all surveillance data that have been reported on maize from different parts of Africa (Bankole et al., 2006). Fumonisins have been implicated in a number of animal diseases such as leucoencephalomalacia in equines, which involves a massive liquefaction of the cerebral hemisphere of the brain with neurological manifestations such as abnormal movement, aimless circling, and lameness. These toxins are also responsible for porcine pulmonary edema, rat liver cancer and haemorrhage in the brain of rabbits (Marasas, 1995).

Fumonisin B1 is followed by ZEA. This mycotoxin acts as a xenoestrogen and is considered as an endocrine disruptor (Schoevers et al., 2012) that could significantly damage thymus and spleen of mice (Liang et al., 2010).

In temperate regions DON toxicity studies in animals have targeted a specific toxicological outcome or mechanism, and thus provided insight into potential hazards (Pestka and Smolinski, 2005). Many studies of host resistance, mitogen-induced lymphocyte proliferation, and humoral immune response have yielded a common theme that trichothecenes are both immuno-stimulatory and immunosuppressive depending on dose, exposure frequency and timing relative to functional immune assay (Pestka et al., 2004). 
Table 1 shows the important mycotoxins (aflatoxins, fumonisins, desoxynivalenol, ZEA, and patulin) and effect on health.

\subsection{Economicals consequences}

Mycotoxins importance as public health issue has led various countries to setup maximum tolerated limits for these compounds in foods. The existence of such regulations can represent a strong limit to international trades and lead to important economic losses.

In the case of Africa, the European Union regulation on aflatoxins costs $\$ 670$ million each year due to limitation of exports of cereals, dried fruits, and nuts (Annan, 2001). Food products rejected for exportation are consumed locally and can lead to exposure to high concentrations of toxins. For instance, the greatest recorded fatal mycotoxins-poisoning outbreak caused by mycotoxin (aflatoxin) occurred in Africa in 2004 (Wu, 2004).

In developed economies, where mycotoxins contamination in foods and feeds chains is tightly regulated to reduce human and animal exposure, the additional costs to meet the economic burden of regulating the foods and feeds supply is supported by the producer and/or the consumer. In a study of Wu (2004), an empirical economic model for mycotoxins impact suggests that, if a regulation limit of fumonisins in foods of $2 \mathrm{mg} / \mathrm{kg}$ would be adopted internationally, the export losses for USA, China and Argentina would range between $\$ 20$ and $\$ 40$ million annually, with a total loss of about $\$ 100$ million. If a more stringent fumonisin regulations, such as the formerly proposed EU standard of $0.5 \mathrm{mg} / \mathrm{kg}$, is adopted as a worldwide norm, the estimated losses linked to limitation of corn export would rise to $\$ 170$ million in the USA, $\$ 60$ million in China, and $\$ 70$ million in Argentina for a total of about $\$ 300$ million each year.

This could also have consequences on animal health and production (Shier et al., 2005; Bryden, 2012). Indeed, those developing regulations for the risk management of mycotoxins seek to balance the need to protect human health with economic concerns that requires a very detailed risk assessment process (Kuiper-Goodman, 2004).

Another difficulty could result from the long period that is often required for transportation of crops from rural and commercial farmers of the commodity to the distribution centre of the importing country. Inappropriate transporting and storage conditions may offer considerable opportunities for moulds to grow, leading to alteration and/or mycotoxin appearance. Economic losses related to fungal and mycotoxin contamination are also a result of the decreased yields associated with mould infection of plants, costs incurred by inspection, sampling and analysis before and after shipment, losses attributed to compensation paid in case of claim, farmers subsidies to cover losses, research training and extension program costs and costs of detoxification (Sibanda et al., 2010).

As a result, mycotoxins appear as important contaminants with significant impacts on human and animal health, but that also have also economic and international trade implications (Wu, 2004; Bryden, 2007; Wild, 2007; Wild and Gong, 2010). The supply of meat, milk and eggs, the human food products of animal production, can also be adversely affected by mycotoxins due to their adverse effects on breeding performances. 


\section{Importance of cassava}

\subsection{Production of cassava in the world}

Ranked 10th among the top 20 agricultural commodities produced in the world, and third most important food crop in tropical regions after rice and maize (FAO, 2011), cassava represents an important part of the diet of almost one billion people or who it represents one main source of energy. Its global production is estimated at 250 million tons (FAO, 2011). Figure 1 shows the geographic distribution of cassava production and exporting countries in the world. Among producing regions, Africa accounts for more than half $(150 \mathrm{Mt})$ of the global supply. Nigeria, which alone accounts for about a third of the production of Africa (45 Mt), is also by far the world's largest producer followed by the Democratic Republic of Congo (DRC) with about $15 \mathrm{Mt}$, Angola and Ghana (12 Mt each) and Mozambique $(9 \mathrm{Mt})$. Asia contributes to about one third of world's production, $60 \%$ being produced by Thailand (about $25 \mathrm{Mt}$ ) and Indonesia $(22 \mathrm{Mt}$ ). China and Vietnam appear as increasing producers and each of these countries produces between 9 and 8 million tons per year since 2008. India, now the third largest producer of cassava in Asia, also displays a continuous growing production with more than $30 \%$ of increase between 2006 and 2010. In Latin America and the Caribbean, the production is relatively stable between 2006 and 2009 at about $35 \mathrm{Mt}$, which represents nearly $20 \%$ of world supply. Brazil dominates with about $70 \%$ of regional production (Gamal et al., 2012). The other two significant producers are Paraguay (approximately $5 \mathrm{Mt}$ ) and Colombia (1.5 to $1.7 \mathrm{Mt}$ ) (UNCTAD, 2012).

Cassava production is primarily used for human consumption. It represents staple food and a major contributor to food security in producing areas and Africa consume almost its entire production. Cassava products, fermented or not, are also devoted to foodstuff (Akoroda, 2007). Cassava can be used for animal feed but this is done mainly in Brazil and Colombia where about half of the production is devoted to such use. The remainder is dedicated to food of local population and exportation to Nigeria, China, the Netherlands and Spain.

\subsection{Economic importance}

On the economic front, $10 \%$ of the world production of cassava is traded. In recent years, flows to Asia were strongly accelerated to such an extent that Asia accounts for $98 \%$ of world imports and $97 \%$ of exports. It was in 2001 that, for the first time, imports of cassava in developing countries have surpassed developed countries. Since then, international flows focused on Asia, especially China.

The Asiatic continent is the largest importer of cassava roots with $6.247 \mathrm{Mt}$ out of a total of $6.392 \mathrm{Mt}$ in 2010. China alone imports more than $92 \%$ of Asian importations, and purchases have tripled since 2001. This interest in cassava is explained by the dynamism of the ethanol industry: China is now the third largest producer of ethanol after the USA and Brazil. Beijing's decision in 2007 not to use grain to produce biofuels in order to preserve their food security has undoubtedly boosted demand for cassava. Currently, 50\% of ethanol production is from cassava and sweet potato (FAO, 2010). 
Main destination for world exports of cassava for a long time, mainly as pellets for animal feed, the European Union, which applies for annual tariff quotas for imports of cassava and tapioca starch, became a minor player with volumes that fluctuate according to the European grain market (FAO, 2010). Since 2009, the abundance of community supplies of feed grains has contributed to the decline of cassava importations (UNCTAD, 2012).

Figure 1 Cassava production and exportation flux in the world

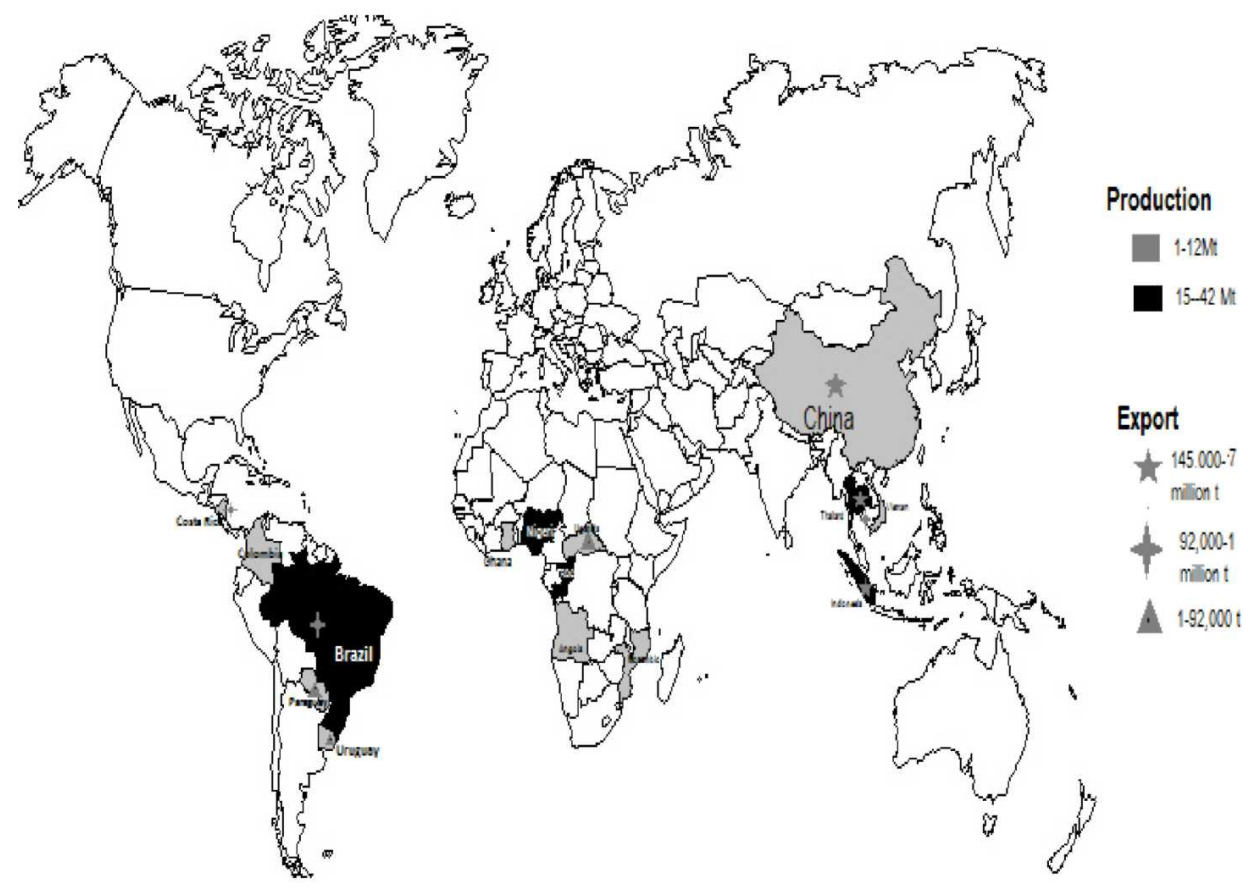

Notes: Africa is the first cassava producer with in order: Nigeria, Democratic Republic of Congo, Angola, Ghana and Mozambique. Asia is in second ringed with: Thailand, Indonesia, Vietnam, China and India. The third position is occupied by America Caribbean: Brazil, Paraguay and Colombia. Other low producers are also encountered on the continents mentioned above.

For commercialisation, Asia accounts for $97 \%$ of world exports. Thailand leading with 4-4.5 Mt per year followed by Cambodia, Vietnam, Indonesia, Costa Rica Paraguay and Uganda.

Thailand is a leading exporter of cassava and dominates the market. It exports annually about $4 \mathrm{Mt}$ of roots, and approximately 4.5 million tons of chips, of which $4.4 \mathrm{Mt}$ to China (UNCTAD, 2012). Volumes are also relatively stable in Indonesia with 145,000 tons of cassava exported while Vietnam and to a lesser extent Cambodia recorded a significant increase in exports: Vietnam went from 304,000 tons in 2006 to $1 \mathrm{Mt}$ in 2010. On the same way, Cambodia, virtually non-existent before 2008, when the country embarked on the production of ethanol, amounted to 345,000 tones in 2009 and 128,000 tons in 2010 (UNCTAD, 2012). 
Outside Asia, Costa Rica exported 92,000 tons in 2010 mainly towards the US market (70\% of the exports) while Paraguay devotes all of its exports to Brazil (UNCTAD, 2012).

In Africa, Uganda is the only African country that is distinguished by its exports to Burundi, Rwanda and the Democratic Republic of Congo (UNCTAD, 2012).

Like many other commodities, the export prices of flour and starch in Thailand (Bangkok FOB), have been appreciated especially during the second half of the last decade. Over the last 11 years, they have been multiplied by more than three and went from $\$ 146.15$ per ton in January 2000 to $\$ 509.21$ per ton in May 2011, with a highest cost recorded in August 2010 at $\$ 630$ per ton following a poor harvest in Thailand. Since then, prices are ranging between $\$ 500$ and $\$ 600$ a ton.

\subsection{Nutritional importance}

The drive for attainment of foods self-sufficiency in developing countries requires total exploitation of all potential sources of nourishment. Hence, the search for an alternative will go a long way in solving the problem of competition. Cassava (Manihot esculenta Crantz) is rich in carbohydrates but low in protein. The food crisis of 2008 has strengthened African Governments in their policy development of cassava cultivation and promotion of consumption, especially by mixing flour of cassava and wheat to make bread. Besides its own favourable characteristics such as high yields per hectare, low input requirement or tolerance to drought, cassava has the advantage of being able to stay in the ground for over one year and then be harvested in case of food shortages or rising grain prices. Cassava makes a greater contribution to total calorie intake in Africa than maize or sorghum. The roots are normally processed or consumed while the peels are being discarded as waste. However, these parts could be also used in animal feeding. Cassava leaves, as by-products of roots harvest, are (depending on the varieties) rich in proteins, minerals, vitamins B, C and carotenes (Ravindrian and Blair, 1992; Adewusi and Bradbury, 1993; Aletor and Adeogun, 1995). The only handicap remains fragility and once harvested they cannot be easily transported.

Regarding peels, Iyayi and Tewe (1994) reported that cassava peel meal could make up to $40 \%$ of the diet of fryer rabbits without any deleterious effects on performance. Cassava peels, leaves, petioles and stems have been incorporated at different levels in livestock feeds (Ikwelle, 1999; Tewe and Kasali, 1986). The main factor limiting the use of cassava roots is their cyanide content that affects nutrient utilisation in livestock animals. Agunbiade et al. (2002) reported the hydrocyanic content of cassava peel meal to be $27 \mathrm{mg} / \mathrm{kg}$. Symptoms of cyanide toxicity include increased respiratory rhythm, increased pulse rate and spasmodic muscular movements (Oke, 1969). Several processing methods like cooking, sun drying and roasting have been used to reduce the cyanide content of cassava products and improve cassava utilisation in practical livestock nutrition (Iyayi and Tewe, 1994; Oguntimein, 1992; Omole, 1977).

\subsection{Cassava derivatives}

In Africa, Caribbean and Pacific (ACP), cassava is consumed as fresh roots or products of primary processing after being peeled, grated or soak into water to ferment (attieke, lafun) and as wet mash (fufu) or varied dry products (tapioca, gari, chip/crumbs/chunks, 
or milled into flour) (Akoroda, 2007); it is also a source of income in urban areas. Cassava consumption was about $115 \mathrm{~kg}$ per capita in 2010 in the ACP countries against $18 \mathrm{~kg}$ for the rest of the world (UNCTAD, 2012). Ugwu and Ay (1992) has classified cassava products into nine groups as follows: $\mathrm{S}$ cooked fresh roots; $S$ - cassava flour: fermented and unfermented; from chips or lafun; $S$ granulated roasted cassava (gari); $S$ granulated cooked cassava (attieke, kwosai); $S$ fermented pastes; $S$ sedimented starches; $S$ drinks (with cassava components); $S$ leaves (cooked as vegetable); $S$ medicines. Their processes are presented in Figure 2(a).

Cassava products can be subdivided into two groups: fermented and non-fermented products.

Fermentation corresponds to the chemical transformation of organic substances into simpler compounds under the action of enzymes that are produced by microorganisms such as moulds, yeasts, or bacteria. Enzymes act by hydrolysing, a breaking down or predigesting phenomenom, complex organic molecules to form smaller (and in the case of foods, more easily digestible) compounds and nutrients (Steinkraus, 1997). Fermented foods are food substrates that are invaded or overgrown by edible microorganisms whose enzymes, particularly amylases, proteases, and lipases hydrolyse the polysaccharides, proteins and lipids to non-toxic products with flavours, aromas and textures pleasant and attractive for the human consumer (Steinkraus, 1997). The longer the fermentation period, the stronger is the sour taste (FAO, 2005).

In this group the following products can be found: gari, fermented chips, fufu, lafu, attieke; and in non-fermented group, cooked roots, tapioca and leaves.

Gari is the most consumed product in West Africa. Demand increases and its processing capacity is reinforcing across the region. The second derivative, fufu, is a popular staple in Ghana, Nigeria, Sierra Leone and other parts of West Africa. Fufu is the second most consumed/sold cassava product in West Africa. Fufu is traditionally made from fresh cassava that is pounded. In recent years, the demand for instant fufu flour has increased since it is faster to prepare and its conservation is longer.

Other traditional products: lafun, granuled products tapioca and attieke are popular processed products made from cassava in West Africa (Padonou et al., 2009; FAO, 2005). Most African traditional products were obtained after a sun-drying step.

Purpose of drying foods is to reduce the amount of free water in the substrate since free water is available for the growth of microorganisms. A significant reduction of water content in a food contributes to curb the proliferation of microorganisms (El Adlouni et al., 2006). Sun-drying is probably the oldest and most common way to reduce the moisture of any crop. It utilises solar energy from the sun directly. The sun's heat allows the free water contained in the food to evaporate and wind causes the water vapour. The air above the product is never saturated with water vapour, which facilitates drying (El Adlouni et al., 2006).

In Africa, cassava is sun-dried on virtually any surface in the open air such as a large flat rock in the field, on the sides of a paved road, on tops of flat roofs, in a flat basket, or on bare ground (FAO, 2005). This traditional mode of solar drying often leads to poor quality products, since they are usually not protected during the drying process, nor against dust, rain and wind or against insects, birds, rodents and pests. This can result in fouling products, exposure to micro-organisms, mycotoxins formation and infection by pathogens (Her and Ankila, 1995). 
Figure 2 Different cassava products process, (a) principal product derivate from cassava (b) production of different cassava chips

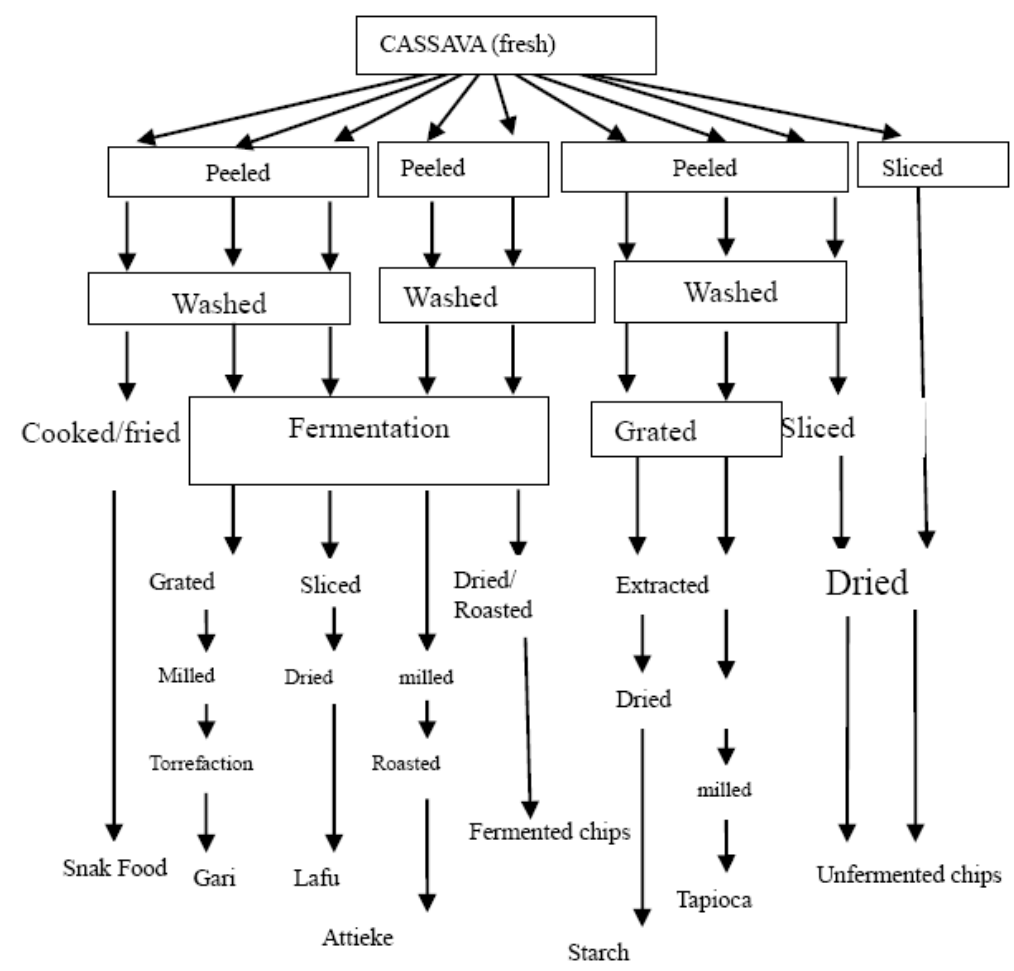

(a)

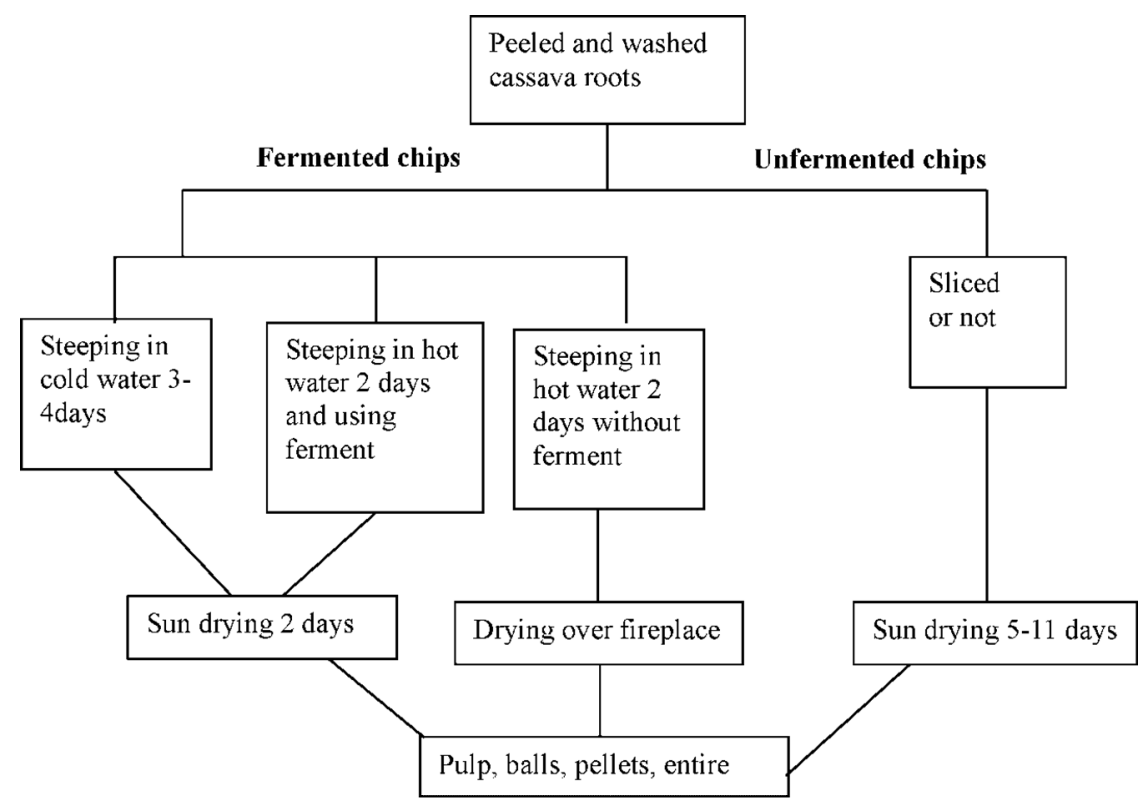

(b) 
Another cassava product is starch, used in the processing of many food products, such as glucose and alcohol, and as an industrial product in the chemical, textile, paint, adhesive glues and laundry industries. Nigeria has sizeable plants average and important manufacture of starch from cassava, exporting their production to large multinational food companies such as Cadbury and Nestle (Djoko, 1995; FAO, 2004).

Flour is the most widely used cassava product in Africa and it is processed in various ways. Drying and milling are the most essential steps. Flours from unfermented cassava roots are more common in areas where sweet cassava varieties dominate. Indeed, because of its high water content, this process is used as a way of preservation. Flour is produced by grinding cassava chips (FAO, 2004, 2005).

The conditions of production and storage of cassava and its derivatives in developing countries, may lead to mould contamination and development. Previous studies have demonstrated the importance of fungal contamination in processed and stored cassava products (Westby and Twiddy, 1991; Kaaya and Eboku, 2010).

\section{Fungi and mycotoxins in cassava products during processing}

Due to its economical and nutritional importance, it appears necessary to ensure safety of cassava products and limit the presence of contaminants that may be hazardous for human health among which moulds are of special importance. An uncontrolled mould development may result in discoloration, quality deterioration, reduction in commercial value and production and accumulation of toxic secondary metabolites in contaminated foods (Krogh, 1992). The potential mycotoxins risk of cassava products is not really evaluated.

The variation of mycotoxins in the cassava chips is greatly depending on production and storage conditions as well as storage duration. Nonetheless a study in Ghana had identified toxins of Aspergillus (patulin, sterigmatocystin, cyclopiazonic acid), Penicillium (penicillic acid), Phoma or Alternaria (tenuazonic acid) species (Wareing et al., 2001). Most of the samples of this study were unpeeled cassava, washed and sun-dried before storage in house.

In cassava chips flour from Uganda and Ivory Coast, Westby et al. (1994) identified neosolaniol, T-2 toxin and diacetoxyscirpenol (Fusarium sp), patulin, cyclopiazonic acid, penicillic acid. In 2009, Manjula et al. (2009) detected low level of aflatoxin (0.3-4.4 ppb in chips and flour; $0.1-13 \mathrm{Mg} / \mathrm{kg}$ in stored chips) in cassava samples from Tanzania and Congo, and traces of fumonisins. In this study, the samples corresponded to several form of cassava: fresh, stored, dried, just dried, stored-smoked, non-smoked, and fermented. No relationship between production process and aflatoxin contamination was found.

Another survey conducted in Tanzania, found no aflatoxin contamination of cassava flour from Tanzanian villages produced following a direct drying process (Muzanila et al., 2000). Similarly, works done in Ghana by Wareing et al. (2001), in Nigeria by Jimoh and Kolapo (2008), in Benin by Gnonlonfin et al. (2008,2012) and Adjovi et al. (2013) also showed that fully direct processed cassava chips samples were not contaminated by aflatoxins. 
Table 2 Fungal and mycotoxins contamination of cassava products

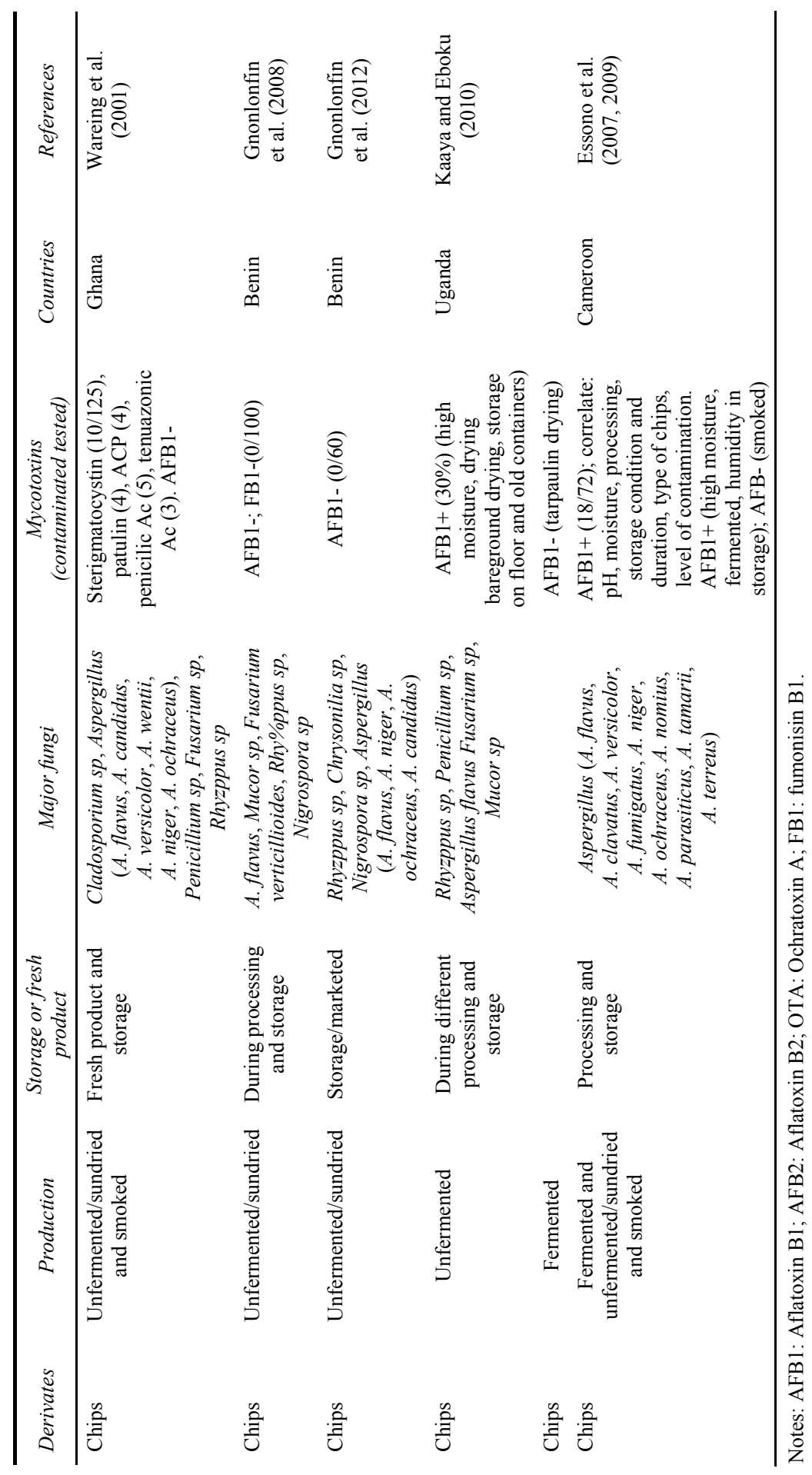


Table 2 Fungal and mycotoxins contamination of cassava products (continued)

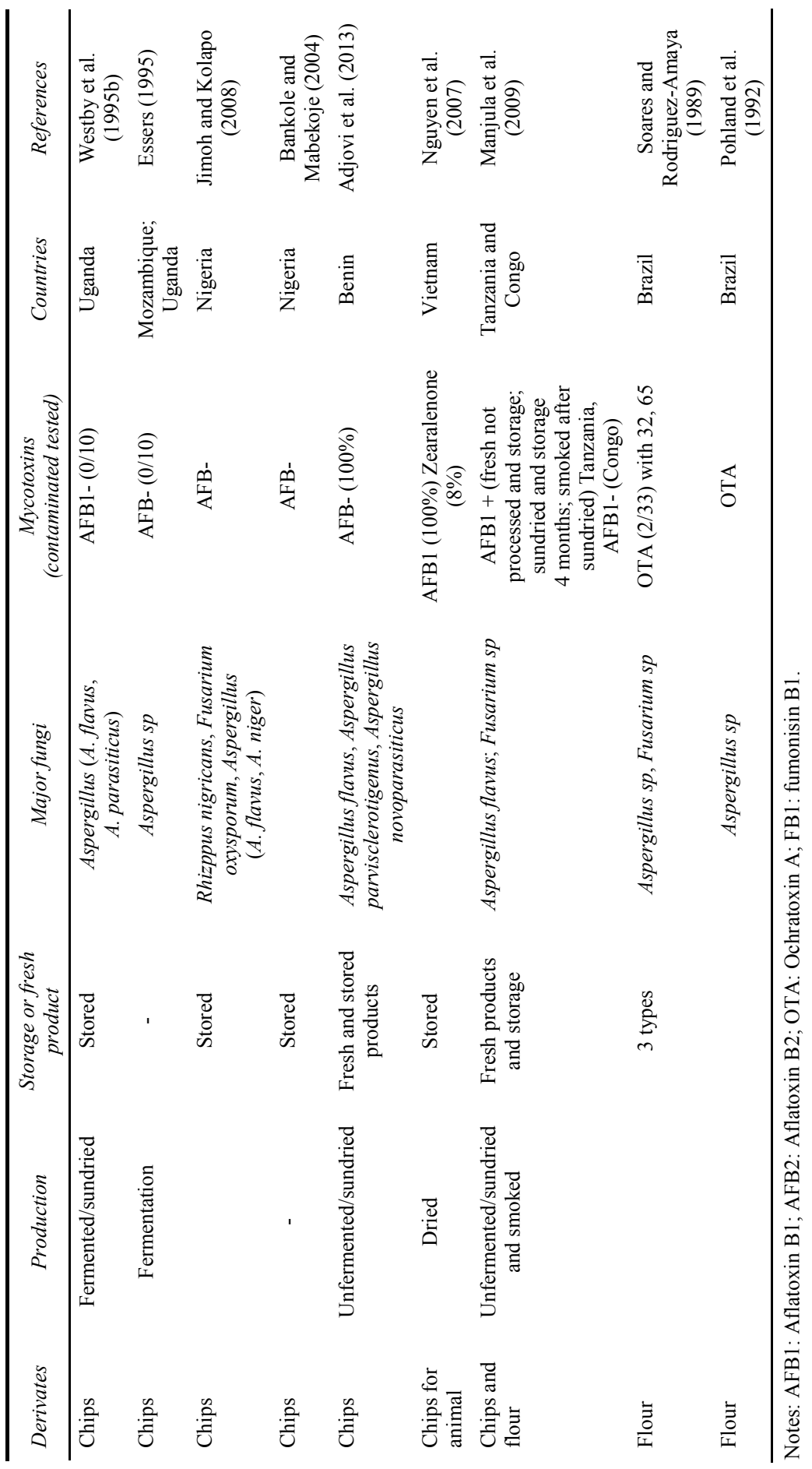


Table 2 Fungal and mycotoxins contamination of cassava products (continued)

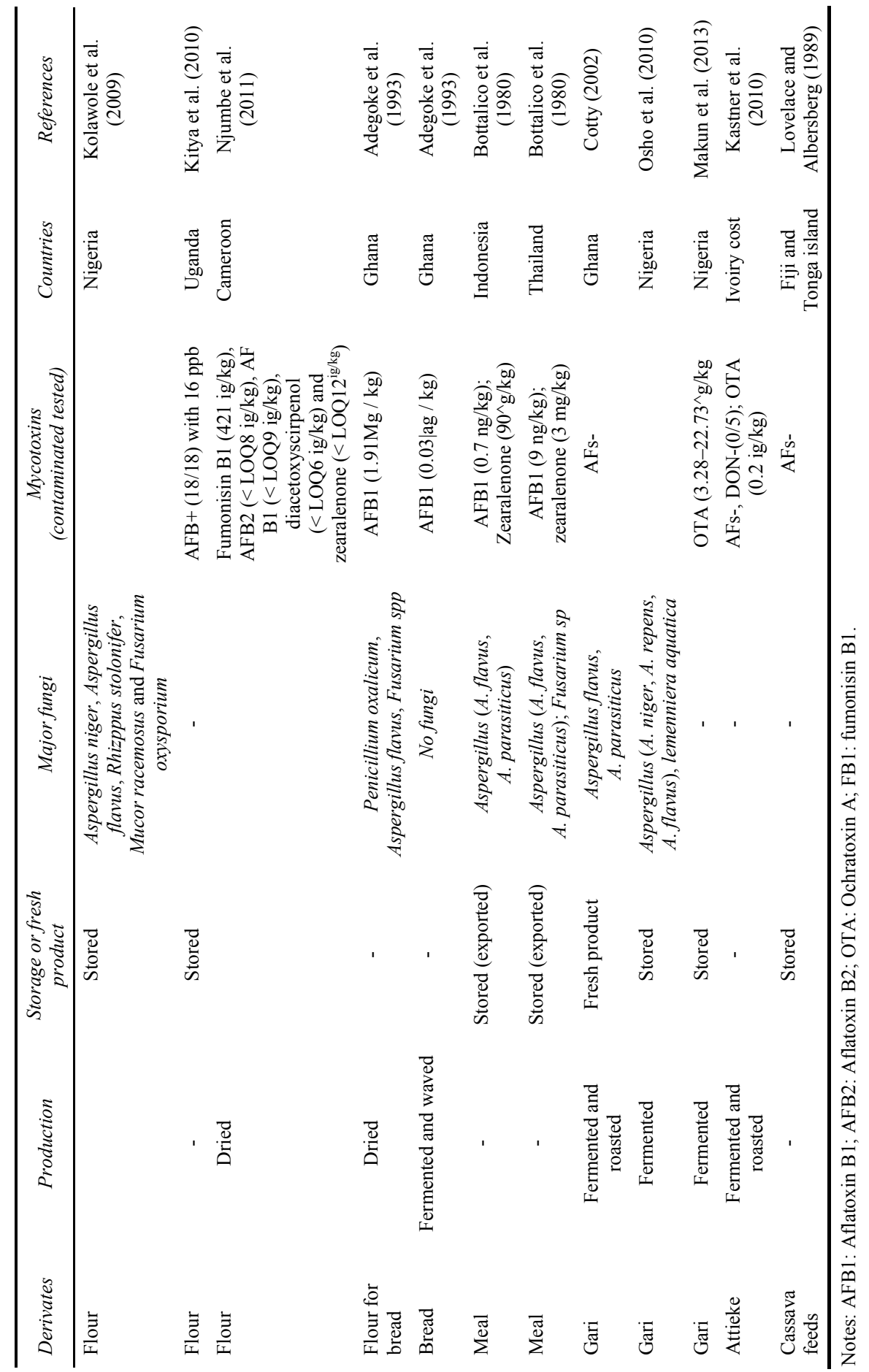


Recently, several studies aimed to establish prevalence of key mycotoxins in Africa have been initiated, although only a few have been carried out in Tanzania, Benin, and all have focused on aflatoxins and fumonisins. In Benin, Adjovi et al. (2013) have shown the presence of toxigenic strains of Aspergillus of the Flavi section in cassava chips produced and sold in Benin, but no presence of aflatoxins was observed. This study also revealed the presence of new species of genus Aspergillus which are aflatoxigenic: Aspergillusparvisclerotigenes and Aspergillus novoparasiticus. Table 2 shows different types of fungi and mycotoxins found in cassava products.

Cassava products contamination begins at pre-harvest and may also occur later, depending on transformation processes and storage conditions.

\subsection{Pre-harvest and harvest conditions}

Pre-harvest fungal contamination is due to cultural practices including crop rotation, cropping pattern, irrigation, planting and harvesting (Kumar and Kumari, 2010). During this stage some fungi can grow on plants and produce mycotoxins (Cwalina-Ambroziak, 2004). The surface of tubers can be contaminated by various soil fungi that penetrate into the tissues through injuries caused by devastators (Jesenska et al., 1993). The main fungi found at pre-harvest stage are Fusarium sp. with species such as $F$. graminearum, $F$. oxysporum, $F$. avenaceum, $F$. moniliformes that are met in potatoes, maize and wheat; Alternaria sp. with Alternaria solani and Alternaria alternata in potatoes, Alternaria infectoria in maize (Jesenska et al., 1993; Cwalina-Ambroziak and Czajka, 2000; Sorensen et al., 2010), Phoma sp. with Phoma exigua in potatoes and Phomapomorum in maize (Sorensen et al., 2010). Among pre-harvest fungi the most important mycotoxin producers are Fusarium and Alternaria (Sorensen et al., 2010). During pre-harvest, the microorganisms of soil and the insects attack may also cause damage on cassava crops. As for other crops, the principal genera that contaminate cassava are Aspergillus, Fusarium and Alternaria (Sorensen et al., 2010; Atanda et al., 2011).

The proximity of cassava and cereals culture can be responsible for cross-contamination by cereals' fungi.

Field fungi invade developing and mature seeds before harvesting. These kinds of mycobiota were found in cassava chips sold in Benin (Gnonlonfin et al., 2008, 2012).

As for cereals, cultural practices and pre-harvest conditions also contribute to microbial contamination of cassava crops. The drying season, the rapid variation of temperature, the presence of insects and the previous usage of the soil by another culture can favour high microbial contamination (Wicklow, 1994).

\subsection{Processing and storage of cassava and derived products}

Without special precautions, cassava roots are not conserved beyond 3 or 4 days. But there are some techniques to prolong the fresh root storage time until about 2-8 weeks. To achieve conservation of several months, it is essential to transform the roots of durable products such as chips, gari, etc. Due to their perishable nature, storage of fresh cassava roots is little practiced in Africa. Traditional methods to prolong the shelf life include the practice of pruning the plant three weeks before harvest, store in pits, pack them and water them, coat them with mud or stored under water. Even in this case, the roots will deteriorate after a few days. Many farmers prefer to leave while cassava in the fields until they need it (FAO, 2000). 
After harvest, the aim is to reduce the time to process or use. Considering the distances between the production areas and the main places of consumption, it is very difficult to avoid substantial losses. That is why there is a major interest, economic point of view, to prolong the shelf life of cassava.

Among the preservation techniques used include:

- storage in silo pits is covered with a thatched roof

- storage in moist sawdust

- immersed in a fungicide and bagging polyethylene

- coating with wax

- refrigerated storage

- storage under plastic sheeting roots soaked in water.

All methods may include the retention period of one or two weeks. But these methods still have some drawbacks such as cost (fungicides, refrigeration), lack of ability to control the quality of the roots and the possibility of attacks by rodents (FAO, 2000).

The fact that cassava roots quickly rot is one of two principals reasons of the common cassava processing wherever it is grown and consumed. The second reason is related to the need to make consumables roots man removing cyanogenic glycosides. To increase the shelf life, it is necessary to reduce the water content, either by drying or by roasting. The two dry goods processing the most popular-cassava are the chips (root dried pieces) and Gari, a fermented cornmeal. Chips and Gari easily keep bags in a cool, dry-in rights for about a year. However, it should inspect the products regularly (at least once a month) in order to monitor the quality as they are hygroscopic (meaning they absorb water) and that the chips be little wind attacked by storage pests (FAO, 2000). The studies on cassava products mainly interested on chips (fermented or not) in Africa and few concerned attieke, meal and flour. The contamination of cassava products by fungi is studied according to different process applied to chips production and mostly the presence or absence of fermentation step.

\subsection{Production of fermented and non-fermented products}

Fermented products often contain mixed microbial populations because of the lack of sterility and the use of natural (spontaneous) fermentation or mixed-culture fermentation starters. In Asia, fungi are used for their enzymatic ability to degrade polymeric substances, as well as for texture forming properties. The main fungi encountered in Asian fermented food are Rhizopus sp. (in tempeh), Monascus sp. (in fermented rice), Actinomucor sp. (Ac. elegans in fermented sojae) and Aspergillus sp. (A. oryzae, A. sojae in soy sauce). In Africa, the use of mycelial fungi for fermentation is less common in the fermentative detoxification of bitter cassava roots (Nout and Aidoo, 2010).

In fermented cassava derivatives, the fermentation can be accomplished by two ways: stacking in heaps or soaking in water for a certain period. The fermentation process, whether in water or in heaps, influences the taste of the final product (FAO, 2005).

Generally, the microorganisms associated with cassava fermentation are mostly lactic acid bacteria (Lactobacillus plantarum, Streptococcus faecium and Leuconostoc mesenteroides) and spore-forming bacteria such as Bacillus sp. (Bokanga, 1989; 
Nwankwo et al., 1989; Okafor et al., 1984; Ngaba and Lee, 1979). Nevertheless, the most important microorganisms are fungi belonging to genus Rhizopus, Mucor, Actinomucor, and Neurospora (Steinkraus, 1997).

During the production of cassava-fermented chips, the use of ferment (starter) likely occurs as a result of the carryover of these ferments contained in the water used during the soaking process. Some studies demonstrate that bacteria that are present in the fermented foods could prevent the contamination with mycotoxins. It is the case during the fermentation of Meju by Bacillus subtilis which reduces the production of aflatoxin B and G by Aspergillus parasiticus (Park et al., 2003). A study of Essono et al. (2007) on fermented chips produced in Cameroon, demonstrated that the predominant fungi isolated from the analysed samples belong to the genus Aspergillus and especially to the following species: A. clavatus, A. flavus, A. niger and Aspergillus versicolor. Other species of the genus Aspergillus were identified in this study. They belonged to the Flavi section: A. nomius, A. tamarii and A. parasiticus; and to other sections as well: A. aculeatus, A. candidus, A. flavipes, A. fumigatus, A. ochraceus, and A. terreus. This study correlates the presence of aflatoxin B1 to fermentation and high moisture of cassava chips (Essono et al., 2009). Essers (1995) noted the absence of aflatoxin B1 in fermented cassava chips with low moisture. In another study, cassava fermented product like gari, which is fermented and roasted with low moisture content, and despite the presence of Aspergillus flavus and Aspergillus parasiticus, once again no aflatoxins were detected (Westby, 2001). By contrast, in the study of Kastner et al. (2010) on Attieke, ochratoxin A (OTA) has been detected $(0.2 \mathrm{ug} / \mathrm{kg}$ ). In cassava flour, Njumbe et al. (2011) have detected fumonisin B1 $(421 \mathrm{ug} / \mathrm{kg})$. The presence of mycotoxins does not depend only on fermentation process but also on other parameters like moisture content, temperature, drying process and conditions.

In the case of non-fermented cassava, after peeling, cassava is washed with fresh water and transformed directly. During non-fermented chips production the peeled roots may be sliced to reduce the size of the pieces before drying (Kaaya and Eboku, 2010). The drying is done on roof or on bare ground, rock surface, tarpaulin, iron sheets and mats [Figure 2(b)] (Gnonlonfin et al., 2008; Kaaya and Eboku, 2010). A survey on cassava chips processing areas in Benin, Ghana and Nigeria (Gnonlonfin et al., 2008; Wareing et al., 2001) has indicated that, despite low moisture of chips, the most common fungi were Rhizopus sp. and Aspergillus sp. In these studies, authors have detected the presence of sterigmatocystin, patulin, cyclopiazonic acid, penicillic acid, tenuazonic acid (Wareing et al., 2001), but not aflatoxin B1 and fumonisin B1 (Gnonlonfin et al., 2008) despite the presence of Aspergillus flavus and Fusarium sp. In case of high moisture associated with inadequate drying condition, aflatoxin B1 has been detected in cassava chips (Kaaya and Eboku, 2010). Table 2 shows cassava products processing and relationship with contamination by fungi and mycotoxins.

\subsubsection{Sun-dried products}

During the drying, some moulds can develop such as Penicillia (Flannigan, 1970) [and produce ochratoxin A (OTA)] (El Adlouni et al., 2006), Aspergillus sp. and Alternaria sp. (Jackson and Al-Taher, 2008). In cassava derivatives, fungi proliferate when the moisture content exceeds $14 \%$. And then, a relationship between drying process and mould contamination was observed. The influence of drying process on the sensitivity to 
aflatoxin contamination has also been reported for other products such as figures (Ozer et al., 2012).

A study of Wareing et al. (2001) has reported that fire-dried cassava gave counts of 10 to $10^{2} \mathrm{cfu} / \mathrm{g}$ less than sun-dried. When the dried chips were obtained after fermentation process, moulds observed on products were white, black, or orange (Kaaya and Eboku, 2010). The presence of greenish moulds could also occur and could be attributed to insufficient first surface drying step.

In Uganda, Kaaya and Eboku (2010) reported that the majority of farmers dry the cassava products on bare ground or bare rocks and this method exposes the crop to contamination with soil, dust, moulds because the soil is the primary source of moulds (Diener et al., 1987).

\subsubsection{Storage of cassava products}

Storage fungi include all species of Aspergillus, Fusarium and Penicillium genera. The growth of fungi during storage is governed by moisture and temperature, but also biotic factors like competition or the presence of insects (Atanda et al., 2011).

Indeed, storage fungi are much more frequent in lots infested by insects, because insects generate moisture and distribute fungi spores in the commodity. Storage fungi require a relative humidity of, at least, $65 \%$ (or a water activity of aw $=0.65$ ), which is equivalent to an equilibrium moisture content of $13 \%$ in grains and cassava chips (Atanda et al., 2011; Gnonlonfin et al., 2012). They grow at temperature ranging from 10 to $40^{\circ} \mathrm{C}$ (Atanda et al., 2011).

Storage of harvested grains at $>10 \%$ moisture content and for prolonged period in poor storage facilities may cause proliferation of moulds on grains (Ominski et al., 1994; Abdalla, 1998; Ahmed et al., 2009). Similarly unwholesome practice of mixing grains of different grades in order to improve the quality of contaminated grains, especially when one contains a large number of fungi spores, will provide inoculum for the good grade and probably contaminate the toxin-free grain (Wagacha and Muthomi, 2008). Other compelling factors adduced by the authors that worsen the fungi and mycotoxins burden in Africa are: public ignorance of the existence of the toxins; complete absence or lack of enforcement of regulatory limits and introduction of contaminated food into the food chain, which has become inevitable due to shortage of food supply caused by drought, wars and other socio-economic and political insecurity.

\subsection{Particular case of aflatoxin contamination}

Among all moulds and mycotoxins found in cassava, only Aspergillus flavus and aflatoxin contamination remain blurred. Indeed, previous studies (Brudzynski et al., 1977; Bottalico et al., 1980; Adegoke et al., 1993) that focused on the contamination of cassava by aflatoxin, mentioned its presence revealed by thin layer chromatography whereas a compound of cassava, scopoletin was interfering the dosage. Indeed, this molecule has the same retention time as aflatoxin. So the first studies have long assumed that cassava products were contaminated with aflatoxin. With the development of new analytical methods for the determination of mycotoxins, some features have permitted to identify exactly the presence aflatoxin in cassava products. 
Surveys that have studied the contamination of cassava by aflatoxin were most interested in chips. So the development of the following paragraph is based on data regarding both fermented and non-fermented cassava chips.

\subsubsection{Relationships between aflatoxin concentration and processing practices}

The peeling of cassava suppresses its protection and makes it more vulnerable to attack by moulds and possibly subsequent contamination by mycotoxins.

The form of cassava pieces can result in uneven drying which can lead to increase moulds contamination. The direct sun drying of cassava products is likely to shorten the drying period since drying is started immediately after peeling and chipping the cassava roots. Drying on tarpaulin and drying on paved surface were associated with no contamination by aflatoxin. The duration of drying affects the moisture and, in association with temperature that favour fungal growth, may influence aflatoxin production (Kaaya and Eboku, 2010). An experimental quick drying of in-shell Brazil nuts $\left(70-102^{\circ} \mathrm{C}\right.$ during 48 hours) reduced fungal contamination and decreased production of aflatoxin from 11.13 to $4.8 \mathrm{ug} / \mathrm{kg}$ (Pacheco and Scussel, 2006).

Essers et al. (1994) and Kaaya and Eboku (2010) have noted that, in Uganda, the fermented cassava chips are more contaminated by moulds than non-fermented ones. In that case, level of mycotoxins contamination and specifically aflatoxins contamination is related to the degree of mouldiness.

\subsubsection{Aflatoxin in cassava stored products}

A. flavus produces highest aflatoxin levels at water activity of 0.996 and temperature of $30^{\circ} \mathrm{C}$ between $5-15$ days of storage (Gqaleni et al., 1997). Additionally cassava chips are hygroscopic and tend to pick up moisture during storage, which promotes moulds and other deterioration agents (Knoth, 1993). The storage in the huts is known to expose the product to rain, which causes the dry pieces to become wet. Usually, cassava products with $12 \%$ moisture can be stored for long time but moisture content greater than $12 \%$ allows microbial growth. For instance, Kaaya and Eboku (2010) have reported an aflatoxin contamination on cassava products contaminated by $A$. parasiticus in Uganda, at $40 \%$ moisture.

The cassava chips can be stored from one week to one year. A short storage period averaging 8-12 weeks reported in the study of Wareing et al. (2001) in Ghana, reduce the risk of contamination by aflatoxins. The storage of cassava product for a long time is one important factor predisposing the products to aflatoxin contamination (Kaaya and Eboku, 2010; Wareing et al., 2001).

Kaaya and Eboku (2010) reported that storing cassava in Jerricans would lead to a 34 times higher contamination while storage in polypropylene bags and heaping on bare floor would lead to 19 to 16 times increased contamination compared to other conditions.

Storage of cassava chips with other agricultural commodities prone to mould contamination promotes cross-contamination (Bankole and Eseigbe, 2004).

The chips are most often stored with grain crops especially corn which can be heavily contaminated with A. flavus and aflatoxin. This proximity may contribute to the transfer of toxigenic mould spores on cassava chips. 


\section{Conclusions}

Cassava is a highly nutritious substrate favouring the growth of microorganisms. Its transformation into different derivatives, though ensuring the availability of the food during welding does not guarantee the absence of the development of moulds.

Consequently, studies have revealed in cassava products, a diverse mycobiota according to the area of production. But the predominance of the genus Aspergillus is however noted. Moulds found can produce mycotoxins in the processed cassava such as ZEA, fumonisins, penicillic acid, patulin and ochratoxin A. In several studies, the absence of aflatoxin in cassava was highlighted. Yet, the few studies that have found this mycotoxin show that its presence is related to the manufacturing process, production and storage conditions that accelerate the physiological deterioration (fermentation) and degradation. Adjovi et al. (2013) have proved the existence of anti-aflatoxin property in fresh cassava, independently of geographical origins. This data suggest that cassava compounds have the ability to block toxinogenesis leading to Aspergillus secondary metabolites. However, this property was lost after processing: heating, sun drying and freezing.

\section{References}

Abdalla, A.E. (1998) An Evaluation of the Durability of Sorghum Grains in Traditional and Modified Underground Pits in Central Sudan, PhD thesis, University of Gezira, Wad Medani, Sudan.

Adaku, C.C., De Kock, S., Zanele, P.Z., Mwanza, M., Egbuta, M.A. and Dutton, M.F. (2012) 'Fungal and mycotoxin contamination of South African commercial maize', J. Food Agric. Environ., Vol. 10, No. 2, pp.296-303.

Adegoke, G.O., Adegoke, G.O., Akinnuoye, D.E. and Akanni, A.O. (1993) 'Effet de la transformation sur la mycoflore et teneur en aflatoxine B1 de manioc sur les produits', Nutrition ursine Human Foods, Vol. 43, No. 3, pp.191-196.

Adewusi, S.R.A. and Bradbury, J.H. (1993) 'Carotenoid in cassava: comparison of open column and HPLC methods of analysis’, J. Sci. Food Agric., Vol. 62, No. 4, pp.375-383.

Adjovi, Y.C.S., Bailly, S., Gnonlonfin, B.J.G., Tadrist, S., Querin, A., Sanni, A., Oswald, I.P., Puel, O. and Bailly, J.D. (2013) 'Analysis of the contrast between natural occurrence of toxigenic Aspergillii of the Flavi section and aflatoxin B1 in cassava', J. Food Microbiol., Vol. 38, pp.151-159.

Agunbiade, J.A., Adeyemi, O.A., Fashina, O.E. and Bagbe, S.A. (2002) 'Fortification of cassava peels in balanced diets for rabbit', Nigeria J. Anim. Prod., Vol. 28, No. 1, pp.167-173.

Ahmed, N., Abdalla, E., Adam, A.E. and Betjowck, Y.S. (2009) 'Fungi and mycotoxins associated with Sorghum grains in major storage systems in Gedarif, Sudan', A Paper submitted to the 17th Board of Directors Meeting of the National Council for Mycotoxins, December, Sudanese Standards and Measurements Organisation, Sudan.

Akoroda, M.O. (2007) 'Cassava consumption and marketing in West-Africa', Atelier 'Potentialites a la transformation du manioc en Afrique de l'Ouest' - Abidjan, 4-7 June, pp.2-23.

Aletor, V.A. and Adeogun, O.A. (1995) 'Nutrients and anti-nutrient components of some tropical leafy vegetables', Food Chem., Vol. 54, No. 4, pp.375-379.

Alexopoulos, C.J., Mims, C.W. and Blackwell, M. (1996) Introductory Mycology, p.17, John Wiley and Sons, ISBN 0471522295, p.17. 
Annan, K. (2001) Third United Nations Conference on the Least Developed Countries [online] http://www.globalpolicy.org/socecon/un/unctad/2001/anna0514.htm (accessed December 2003).

Atanda, S.A., Pessu, P.O., Agoda, S., Isong, I.U., Adekalu, O.A., Echendu, M.A. and Falade, T.C. (2011) 'Fungi and mycotoxins in stored foods', Afr. J. Micro. Res., Vol. 5, No. 25, pp.4373-4382.

Bankole, S., Schollenbeger, M. and Drochner, W. (2006) 'Mycotoxin contamination in food systems in Sub-Saharan Africa', Mykotoxin Workshop Hrsg.: Bydgosczz (Polen), 29-31 May, Vol. 28, p.37.

Bankole, S.A. and Adebanjo, A. (2003) 'Mycotoxins in food in West Africa: current situation and possibilities of controlling it', Afr. J. Biotech., Vol. 2, No. 9, pp.254-263.

Bankole, S.A. and Eseigbe, D.A. (2004) 'Aflatoxins in Nigerian dry-roasted groundnuts', Nutr. Food Sci., Vol. 34, No. 6, pp.268-271.

Bankole, S.A. and Mabekoje, O.O. (2004) 'Mycoflora and occurrence of aflatoxinB1 in dried yam chips from markets in Ogun and Oyo States, Nigeria', Mycopathologia, Vol. 157, No. 1, pp.111-115.

Bernhoft, A., Keblys, M., Morrison, E., Larsen, H.J. and Flaoyen, A. (2004) 'Combined effects of selected Penicillium mycotoxins on in vitro proliferation of porcine lymphocytes', Mycopathologia, Vol. 158, pp.441-450.

Bokanga, M. (1989) Microbiology and Biochemistry of Cassava Fermentation, $\mathrm{PhD}$ thesis, Cornell University, Ithaca, NY, USA.

Bottalico, A., Lerario, P. and Frisullo, S. (1980) 'Occurrence of aflatoxins, zearalenone and aflatoxigenic strains of Aspergilli in samples of cassava meal', J. Zoo. Nutr. Anim., Vol. 6, No. 3, pp.209-214.

Brudzynski, A., Van Pee, W. and Kornaszewski, W. (1977) 'The occurrence of aflatoxin B1 in peanuts, corn and dried cassava sold at the local market in Kinshasa, Zaire; its coincidence with high hepatoma morbidity among the population', Zesz. Probl. Postepow Nauk. Roln., Vol. 189, pp.189-117.

Bryden, W.L. (2007) 'Mycotoxins in the food chain: human health implications', Asia Pac. J. Clin. Nutr., Vol. 16, Suppl. 1, pp.95-101.

Bryden, WL. (2012) 'Mycotoxin contamination of the feed supply chain: implication animal productivity and feed security', Anim. FeedSci. Tech., Vol. 173, pp.134-158.

Codex Alimentarius (2012) Discussion Paper on Fungi and Mycotoxins in Sorghum, Codex Committee on Contaminants in Foods; FAO/WHO Food Standards Program, Sixth Session Maastricht, The Netherlands, 26-30 March.

Cole, R.J., Scheweikert, M.A. and Jarvis, B.B. (2003) Handbook of Secondary Fungal Metabolites, Vols. 1-3, Acad. Press, CA, USA.

Cotty, P.J. (1992) 'Use of native Aspergillus flavus strains to prevent aflatoxin contamination', US Patent, Vol. 5, pp.171-686.

Cross, D.L. (2003) 'Clavicipitacean fungi: evolutionary biology, chemistry, biocontrol and cultural impacts. Ergot alkaloid toxicity', in White Jr., J.F., Bacon, C.W., Hywel-Jones, N.L. and Spatafora, J.W. (Eds.): Mycology, pp.475-494, Marcel-Dekker Inc, New York and Basel.

Cwalina-Ambroziak, B. (2004) 'Diseases of potatoes and fungi colonizing potato stem bases in dependence on different nitrogen fertilization', Actafyto. Zoo., Vol. 7, Special Number, Proceedings of the XVI, Slovak and Czech, Plant Protection Conference organised at Slovak Agricultural University in Nitra, Slovakia.

Cwalina-ambroziak, B. and Czajka, W. (2000) 'Potato stems infection by Rhhi\%octonia solani and Colletotrichum coccodes in different crop rotation', Phytopathol. Pol., Vol. 20, pp.155-163.

Dean, R., Van Kan, J.A., Pretorius, Z.A., Hammond-Kosack, K.E., Di Pietro, A., Spanu, P.D., Rudd, J.J., Dickman, M., Kahmann, R., Ellis, J. and Foster, G.D. (2012) 'The Top 10 fungal pathogens in molecular plant pathology', Mol. Plant Path., Vol. 13, No. 4, pp.414-430. 
Diener, U.L., Cole, R.J., Sanders, T.H., Payne, G.A., Lee, L.S. and Klich, M.A. (1987) 'Epidemiology of aflatoxin formation by Aspergillusflavuf, Ann. Rev. Phyt., Vol. 25, pp.249-270.

Djoko, S.D. (1995) Food Processing in Indonesia: The Development of Small-Scale Industries, Bogor Research Institute for Food Crops Biotechnology, Agency for Agricultural Research and Development, pp.9-10.

Dorner, J.W., Cole, R.J., Lomax, L.G., Gosser, H.S. and Diener, U.L. (1983) 'Cyclopiazonic acid production by Aspergillus flavus and its effects on broiler chickens', Appl. Environ. Microbiol., Vol.46, No. 1, pp.698-703.

Dyer, D. (1993) 'Evidence that ergovaline acts on serotonin receptors', Life Sci., Vol. 53, pp.223-228.

El Adlouni, C., Tozlovanu, M., Natman, F., Faid, M. and PfohlLeszkowicz, A. (2006) 'Preliminary data on the presence of mycotoxins (ochratoxin A, citrinin and aflatoxin B1) in black table olives 'greek style' of Moroccan origin', Mol. Nutr. Food Res., May, Vol. 50, pp.507-512.

Elegbede, J.A. (1978) Fungal and Mycotoxin Contamination of Sorghum During Storage, MSc Thesis submitted to Department of Biochemistry, Ahmadu Bello University, Zaria.

Essers, A.J.A. (1995) Removal of Cyanogens From Cassava Roots: Studies on Domestic Sun-Drying and Solid Substrate Fermentation in Rural Africa, PhD Thesis, Wageningen Agricultural University, The Netherlands.

Essers, A.J.A., Witjes, C.M.J.W., Schurink, E.W. and Nout, M.J.R., (1994) 'Role of fungi in cyanogens removal during solid substrate fermentation of cassava', Biotechnol. Lett., Vol. 16, pp.755-758.

Essono, G., Ayodele, M., Akoab, A., Foko, J., Filtenborg, O. and Olemboe, S. (2009) 'Aflatoxin-producing Aspergillus spp. and aflatoxin levels in stored cassava chips as affected by processing practices', Food Cont., Vol. 20, No. 7, pp.648-654.

Essono, G., Ayodele, M., Akoa, A., Foko, J., Olembo, S. and Gockowski, J. (2007) 'Aspergillus species on cassava chips in storage in rural areas of southern Cameroon: their relationship with storage duration, moisture content and processing methods', Afr. J. Micro. Res., May, Vol. 1, pp. $1-8$.

FAO (2000) 'Les richesses du sol. Les plantes a racines et tubercules en Afrique: une contribution aux technologies des recoltes et apres recoltes', in Bell, A., Muck, O. and Schuler, B. (Eds.): Archives Documents de la FAO, GTZ, Allemagne, [online] http://www.fao.org/wairdocs/x5695f/x5695f00.htm (accessed October 2014).

FAO (2001) '2001/2003 manual on the application of the HACCP system in mycotoxin, prevention and control', FAO Food Nutr. Paper, Vol. 73, pp.1-124 [online] http://www.fao.org/docrep/005/y1390e/y1390e00.HTM (accessed December 2012).

FAO (2004) 'The global cassava development Strategy and implementation plan', Proceeding of the Validation Forum on the Cassava Development Strategy, Food and Agriculture Organization of the United Nations [online] http://www.fao.org.

FAO (2005) Food Supply Situation and Crop Prospects in Sub-Saharan Africa: Global Information and Early Warning System (GIEWS), Vol. 3, pp.1-69, Africa Report, Food and Agriculture Organization of the United Nations, Rome, Italy.

FAO (2010) 'Une nouvelle variete de manioc part a l'assaut de la faim en Afrique', Senegal Business, 30 Aout 2010 [online] http://www.fao.org/ag/ags/gestion-apres-recolte/racines-ettubercules /fr (Accessed December 2012)

FAO (2011) 'Global information and early warning system on food and agriculture', FAO Food Outlook: Global Market Analysis, November.

Flannigan, B. (1970) 'Mycoflora of dried barley grain', Trans. Br Myco. Soc., Vol. 53, pp.371-379.

Gamal, A.S., Esam, M. and El-Shishtawy, M. (2012) 'Fumonisin lung toxicity: gross and microscopic changes are dose and time dependent', J. Amer. Sci., Vol. 8, No. 9, pp.729-736. 
Gentles, A., Smith, E.E., Kubena, L.F., Duffus, E., Johnson, P., Thompson, J., Harvey, R.B. and Edrington, T.S. (1999) 'Toxicological evaluations of cyclopiazonic acid and ochratoxin A in broilers', Poultry Science, Vol. 78, No. 1, pp.1380-1384.

Gentles, A.B., Small, M.H., Smith, E.E., Phillips, T.D., Duffus, E. and Braithwaite, C.E. (1993) 'Teratogenic effects of orally administered diacetoxyscirpenol in mice', Toxicologist, Vol. 13, p.208.

Gnonlonfin, G.J.B., Adjovi, C.S.Y., Katerere, D.R., Shephard, G.S., Sanni, A. and Brimer, L. (2012) 'Mycoflora and absence of aflatoxin contamination of commercialized cassava chips in Benin, West Africa', Food Cont., Vol. 23, No. 2, pp.333-337.

Gnonlonfin, G.J.B., Hell, K., Fandohan, P. and Siame, A.B. (2008) 'Mycoflora and natural occurrence of aflatoxins and fumonisin B1 in cassava and yam chips from Benin, West Africa', Int. J. Food Micro., Vol. 122, Nos. 1-2, pp.140-147.

Gong, Y., Hounsa, A., Egal, S., Turner, P.C., Sutcliffe, A.E., Hall, A.J., Cardwell, K. and Wild, C.P. (2004) 'Postweaning exposure to aflatoxin results in impaired child growth: a longitudinal study in Benin, West Africa', Env. Hea. Pen., Vol. 112, No. 13, pp.1334-1338.

Gong, Y.Y., Cardwell, K.F. Hounsa, A., Egal, S., Turner, P.C., Hall, A.J. and Wild, C.P. (2002) 'Dietary aflatoxin exposure and impaired growth in young children from Benin and Togo: a cross-sectional study', Brit. Med. J., Vol. 325, No. 7354, pp.20-21.

Gong, Y.Y., Egal, S., Hounsa, A., Turner, P.C., Hall, A.J., Cardwell, K.F. and Wild, C.P. (2003) 'Determinants of aflatoxin exposure in young children from Benin and Togo, West Africa; the critical role of weaning', Int. J. Epi., Vol. 32, No. 4, pp.556-562.

Gong, Y.Y., Wilson, S., Mwatha, J.K., Routledge, M.N., Castelino, J.M., Zhao, B., Kimani, G., Kariuki, H.C., Vennervald, B.J., Dunne, D.W. and Wild, C.P. (2012) 'Aflatoxin exposure may contribute to chronic hepatomegaly in Kenyan school children', Env. Hea Pers., Vol. 120, No. 6, pp.893-896.

Gqaleni, N., Smith, J.E., Lacey, J. and Gettinby, G. (1997) 'Effects of temperature, water activity and incubation time on production of aflatoxins and cyclopiazonic acid by an isolate of Aspergillus flavus in surface agar culture', App. Env. Micro., Vol. 63, No. 1037, pp.1048-1053.

Hawksworth, D.L. (2006) 'The fungal dimension of biodiversity: magnitude, significance, and conservation', Myco. Res., Vol. 95, No. 6, pp.641-655.

Her, M. and Ankila, O. (1995) 'Manuel du Sechage Solaire au Maroc', Food Nutr. Library, Vol. 2.2, German Agency for Technical Cooperation (GTZ) [online] http://www.nzdl.org.

IARC (1987) IARC Monographs on the Evaluation of Carcinogenic Risks to Humans, Suppl. 7, Overall Evaluations of Carcinogenicity: An Uptading of IARC Monographs, Vols. 1-42, pp.83-87, IARC Press, Lyon.

Ikwelle, M. (1999) Annual Review and Planning Workshop of the National Root Crop Research Institute, 2 February, Ibadan, Nigeria.

International Agency for Research on Cancer (IARC) (1993) 'Some naturally occurring substances: food items and constituents, heterocyclic aromatic amines and mycotoxins', IARC Monographs on the Evaluation of Carcinogenic Risks to Humans, IARC, Lyon, France, Vol. 56, p.489.

Iyayi, E.A. and Tewe, O.O. (1994) 'Cassava feeding in small holder livestock units', ACTA Horticulturae, in International Workshop on Cassava Safety, ISHS No. 375 (Eds.: M. Bokanga, A.J.A. Essers, N. Poulter, H. Rosling and O. Tewe), Ibadan, Nigeria, 1-4 March 1994, pp.261-269.

Jackson, L.S. and Al-Taher, F. (2008) 'Factors affecting mycotoxin production in fruits', in Barkai-Golan, R. and Paster, N. (Eds.): Mycotoxins in Fruits and Vegetables, pp.75-104, Elsevier, California, USA.

Jarvis, B. (1971) 'Factors affecting the production of mycotoxins', J. App. Bact., Vol. 34, No. 3, pp.199-213. 
JECFA (2001) Safety Evaluation of Certain Mycotoxins in Food, FAO/WHO Expert Committee on Food Additives, WHO Food Additives Series 47 and FAO Food and Nutr. Paper, Vol. 74, p.701.

Jesenska, Z., Pieckova, E. and Bernat, D. (1993) 'Heat resistance of fungi from soil', Int. J. Food Micro., Vol. 19, No. 3, pp.187-192.

Jimoh, K.O. and Kolapo, A.L. (2008) 'Mycoflora and aflatoxin production in market samples of some selected Nigerian foodstuffs', Res. J. Micro., Vol. 3, No. 3, pp.169-174.

Johnni, H., Daniel, J.H., Lewis, L.W., Redwood, Y.A., Kieszak, S., Breiman, R.F., Flanders, W.D., Bell, C., Mwihia, J., Ogana, G., Likimani, S., Straetemans, M. and McGeehin, M.A. (2011) 'Comprehensive assessment of maize aflatoxin levels in Eastern Kenya, 2005-2007', Env. Hea. Pers., Vol. 119, No. 12, pp.1794-1799.

Kaaya, A.N. and Eboku, D. (2010) 'Mould and aflatoxin contamination of dried cassava chips in Eastern Uganda: association with traditional processing and storage practices', J. Bio. Sci., Vol. 10, No. 8, pp.718-729.

Kastner, S., Kandler, H., Hotz, K., Bleisch, M., Lacroix, C. and Meile, L. (2010) 'Screening for mycotoxins in the inoculum used for production of attieke, a traditional Ivorian cassava product, LWT', Food Sci. Tech., Vol. 43, No. 7, pp.1160-1163.

Keblys, M., Bernhoft, A., Hofer, C.C., Morrison, E., Larsen, H.J. and Flaoyen, A. (2004). 'The effects of the Penicillium mycotoxins citrinin, cyclopiazonic acid, ochratoxin A, patulin, penicillic acid, and roquefortine $\mathrm{C}$ on in vitro proliferation of porcine lymphocytes', Mycopathologia, Vol. 158, pp.317-324.

Khlangwiset, P., Shephard, G.S. and Wu, F. (2011) 'Aflatoxins and growth impairment: a review', Crit. Rev. Tox., Vol. 41, No. 9, pp.740-755.

Kitya, D., Bbosa, G.S. and Mulogo, E. (2010) 'Aflatoxin levels in common foods of South Western Uganda: a risk factor to hepatocellular carcinoma’, Eur. J. Canc. Care, Vol. 19, pp.516-521.

Knoth, J. (1993) Traditional storage of yams and cas- sava and its improvement, Deutsche Gesellschaft fur Technische Zusammenarbeit (GTZ) GmbH.

Kolawole, O.M., Adeyemi, B.J., Kayode, R.M.O. and Ajibola, T.B. (2009) 'The drying effect of colour light frequencies on the nutrient and microbial composition of cassava', African Journal of Agricultural Research, Vol. 4, No. 3, pp.171-177.

Krogh, P. (1992) 'Adverse effect of mycotoxin on human health', in Mathur, S.B. and Jorgensen, J. (Eds.): Seed Pathology, Proceedings the Seminar, Copenhagen, Denmark, 20-25 June 1988, pp.149-157.

Kuiper-Goodman, T. (2004) 'Risk assessment and risk management of mycotoxins in food', in Magan, N. and Olsen, M. (Eds.): Mycotoxins in Food, Detection and Control, p.7, Woodhead Publishing Limited, Cambridge, UK.

Kumar, A.C. and Kumari, P. (2010) 'Management of mycotoxin contamination in pre-harvest and post-harvest crops: present status and future prospects', J. Phy., Vol. 2, No. 7, pp.37-52.

Lewis, L., Onsongo, M., Njapau, H., Schurz-Rogers, H., Luber, L., Kieszak, S., Nyamongo, J., Backer, L., Dahiye, A.M., Misore, A., DeCock, K., Rubin, C. and The Kenya Aflatoxicosis Investigation Group (2005) 'Aflatoxin contamination of commercial maize products during an outbreak of acute aflatoxicosis in eastern and central Kenya', Env. Hea. Pers., Vol. 113, No. 12, pp.1763-1767.

Liang, Z-s., Ma, Y-j., Liu, C-y., Deng, X-b., Yan, H-k. and Fan, X-1. (2010) 'In vivo toxicity of zearalenone in immune organs of mice', Chin. Vet. Sci., No. 3, pp.279-283.

Lillehoj, E.B. (1973) 'Feed sources and conditions conducive for production of aflatoxin ochratoxin, Fusarium toxins and Zearalenone', J. Amer. Vet. Med. Ass., Vol. 163, No. 2, pp.1280-1283.

Lovelace, C.E. and Albersberg, W.G. (1989) 'Aflatoxin levels in foodstuffs in Fiji and Tonga islands', Plant Food Hum. Nutr., Vol. 39, No. 4, pp.393-399. 
Magro, A., Matos, O., Bastos, M., Carolino, M., Lima, A. and Mexia, A. (2010) 'The use of essential oils to protect rice from storage fungi', Julius-Kiihn-Archiv., Vol. 425, pp.542-547.

Makun, H.A., Adeniran, A.L., Mailafiya, S.C., Ayanda, I.S., Mudashiru, A.T., Ojukwu, U.J., Jagaba, A.S., Usman, Z. and Salihu, D.A. (2013) 'Natural occurrence of ochratoxin A in some marketed Nigerian foods', Food Control, Vol. 31, No. 2, pp.566-571.

Manjula, K., Hell, K., Fandohan, P., Abass, A. and Bandyopadhyay, R. (2009) 'Aflatoxin and fumonisin contamination of cassava products and maize grain from markets in Tanzania and Republic of the Congo', Tox. Rev., Vol. 28, No. 2, pp.63-69.

Marasas, W.F.O. (1995) 'Fumonisins: their implications for human and animal health', Nat. Tox., Vol. 3, pp.193-198.

Marasas, W.F.O. (2001) 'Discovery and occurrence of the fumonisins: a historical perspective', Env. Hea. Pers. Supp., Vol. 109, No. 4, p.2.

Marczuk, J., Obremski, K., Lutnicki, K., Gajęcka, M. and Gajęcki, M. (2012) 'Zearalenone and deoxynivalenol mycotoxicosis in dairy cattle herds', Pol. J. Vet. Sci., Vol. 15, No. 2, pp.365-372.

Meissonnier, G.M., Pinton, P., Laffitte, J., Cossalter, A.M., Gong, Y.Y, Wild, C.P., Bertin, G., Galtier, P. and Oswald, I.P. (2008) 'Immunotoxicity of aflatoxin B1: Impairment of the cell-mediated response to vaccine antigen and modulation of cytokine expression', Tox. App. Phar., Vol. 231, No. 2, pp.142-149.

Mueller, G.M. and Schmit, J.P. (2006) 'Fungal biodiversity: what do we know? What can we predict?', Biod. Cons., Vol. 16, No. 7, pp.1-5.

Muzanila, Y.C., Brennan, J.G. and King, R.D. (2000) 'Residual cyanogens, chemical composition and aflatoxins in cassava flour from Tanzanian villages', Food Chem., Vol. 70, No. 1, pp.45-49.

Ngaba, J.R. and Lee, J.S. (1979) 'Fermentation of cassava (Manihot esculenta Crantz)', J. Food Sci., Vol. 44, No. 4979, pp.1570-1571.

Nguyen, M.T., Tozovanu, M., Tran, T.L. and Pfohl-Leszkowicz, A. (2007) 'Occurrence of aflatoxin $\mathrm{B} 1$, citrinin and ochratoxin $\mathrm{A}$ in rice in five provinces of the central region of Vietnam', Food Chemistry, Vol. 105, No. 1, pp.42-47.

Njumbe, E.E., Di Mavungu, J.D., Monbaliu, S., Van Peteghem, C. and De Saeger, S. (2011) 'A validated multianalyte LC MS/MS method for quantification of 25 mycotoxins in cassava flour, peanut cake and maize samples', J. Agr. Food Chem., Vol. 59, No. 10, pp.5173-5180.

Nout, M.J.R. and Aidoo, K.E. (2010) 'Asian Fungal fermented foods', in Hofritcher, M. (Ed): The Mycota X, Industrial Application, 2nd ed., Springer-Verlag, Berlin, Heidelberg.

Nwankwo, D., Anadu, E. and Usoro, R. (1989) 'Cassava fermenting organisms', Mircen. J., Vol. 5, No. 2, pp.169-179.

Nyathi, C.B., Mutiro, C.P., Hasler, J.A. and Chetsanga, C.J. (1987) 'A survey of urinary aflatoxin in Zimbabwe', International Journal of Epidemiology, Vol. 16, pp.516-519.

Oguntimein, G.B. (1992) 'Processing cassava for animal feeds', in Helm, S.K., Reynolds, S.I.L. and Egbunike, G.N. (Eds.): Proceedings on Cassava in Livestock Feed, 14-18 November, IITA/ILCA, Ibadan, Nigeria.

Okafor, N., Ijioma, B. and Oyolu, C. (1984) 'Studies on the microbiology of cassava retting for foo-foo production', J. App. Bact., Vol. 56, No. 1, pp.1-13.

Oke, O.O. (1969) 'The role of hydrocyanide in nutrition', Wor. Rev. Nutr. Diet., Vol. 11, pp.170-198.

Ominski, K.H., Marquardt, R.R., Sinha, R.N. and Abramson, D. (1994) 'Ecological aspects of growth and mycotoxin production by storage fungi', in Miller, J.D. and Trenholm, H.L. (Eds.): Mycotoxins in Grains. Compounds other than Aflatoxin, pp.287-305, Eagen Press, USA.

Omole, T.A. (1977) 'Cassava in the nutrition of layers', in Nestle, B. and Graham, M. (Eds.): Cassava as Animal Feed, pp.51-55, Ottawa, Canada. 
Osho, A., Mabekoje, O.O. and Bello, O.O. (2010) 'Comparative study on the microbial load of Gari, Elubo-isu and Iru in Nigeria', Afr. J. Food Sci., Vol. 4, No. 10, pp.646-649.

Ozer, H., Oktay, B., Hatice, I. and Ozay, G. (2012) 'Mycotoxin risks and toxigenic fungi in date, prune and dried apricot among Mediterranean crops', Phyt. Medit., Vol. 51, No. 1, pp.148-157.

Pacheco, A.M. and Scussel, V.M. (2006) 'Effects of processing and factory storage on aflatoxin contamination of in-shell Brazil nuts', 9th International Working Conference on Stored Product Protection: Microorganisms, Mycotoxins and Other Biological Contaminant, pp.159-164.

Padonou, W.S., Nielsen, D.S., Hounhouigan, J.D., Thorsen, L., Nago, M.C. and Jakobsen, M. (2009) 'The microbiota of Lafun, an African traditional cassava food product', International Journal of Food Microbiology, Vol. 133, Nos. 1-2, pp.22-30.

Pandiyan, V., Nayeem, M., Nanjappan, K. and Ramamurti, R. (1990) 'Penicillic acid as Na+, K+ and $\mathrm{Ca} 2+$ channel blocker in isolated frog's heart at toxic levels', Indian J. Exp. Biol., Vol. 28, pp.295-296.

Park, K.Y., Jung, K.O., Rhee, S.H. and Choi, Y.H. (2003) 'Antimutagenic effects of doenjang (Korean fermented soypaste) and its active compounds', Mutat Research, Vols. 523-524, pp.43-53.

Patterson, D.S. and Allcroft, R. (1970) 'Metabolism of aflatoxin in susceptible and resistant animal species', Food Cosmet Toxicol., Vol. 8, pp.43-53.

Peraica, M., Radic, B., Lucic, A. and Pavlovic, M. (1999) 'Toxic effects of mycotoxins in humans', Bull. World Health Organ., Vol. 77, pp.754-766.

Pestka, J.J. (2008) 'Mechanisms of deoxynivalenol-induced gene expression and apoptosis', Food Addit. Contam. Part A Chem. Anal. Control Expo. Risk Asse., Vol. 25, No. 1, pp.1128-1140.

Pestka, J.J. and Smolinski, A.T. (2005)'Deoxynivalenol: toxicology and potential effects on humans', Journal of Toxicol Environ Health B Crit Rev., Vol. 8, No. 1, pp.39-69.

Pestka, J.J., Zhou, H-R., Moon, Y. and Chung, Y.J. (2004) 'Cellular and molecular mechanisms for immune modulation by deoxynivalenol and other trichothecenes: unraveling a paradox', Toxicol. Lett., Vol. 153, No. 1, pp.61-73.

Pohland, A.E., Nesheim, S. and Friedman, L. (1992) 'Ochratoxin A: a review', Pure and Appl. Chem., Vol. 64, No. 1, pp.1092-1046.

Probst, C., Njapau, H. and Cotty, P.J. (2007) 'Outbreak of an acute aflatoxicosis in Kenya in 2004: identification of the causal agent', App. Env. Micro., Vol. 73, No. 8, pp.2762-2764.

Pronk, M.E.J., Schothorst, R.C. and van Egmond, H.P. (2002) Toxicology and Occurrence of Nivalenol, Fusarenon X, Diacetoxyscirpenol, Neosolaniol and 3- and 15-Acetylnivalenol: A Review of Six Trichothecenes, p.75, RIVM Report 388802024, Bilthoven, Netherlands.

Rasch, C., Kumke, M. and Lohmannsroben, H-G. (2010) 'Sensing of mycotoxin producing fungi in the processing of grains', Food Biop. Tech., Vol. 3, No. 6, pp.908-916.

Ravindrian, V. and Blair, R. (1992) 'Feed resources for poultry production in Asia and the pacific. II. Plant protein sources', Wor. Pou. Sci., Vol. 48, No. 3, pp.205-231.

Rustom, I.Y.S. (1997) 'Aflatoxin in food and feed: occurrence, legislation and inactivation by physical methods', Food Chem., Vol. 59, No. 1, pp.57-67.

Sancho, L.G., de la Torre, R., Horneck, G., Ascaso, C., de Los Rios, A., Pintado, A., Wierzchos, J. and Schuster, M. (2007) 'Lichens survive in space: results from the 2005 LICHENS experiment', Astrob., Vol. 7, No. 3, pp.443-454.

Schoevers, E.J., Santos, R.R., Colenbrander, B., Fink-Gremmels, J. and Roelen, B.A.J. (2012) 'Transgenerational toxicity of Zearalenone in pigs', Rep. Tox., Vol. 34, No. 1, pp.110-119.

Shank, R.C., Wogan, G.N., Gibson, J.B. and Nondasuta, A. (1972) 'Dietary aflatoxins and human liver cancer: Aflatoxins in market foods and foodstuffs of Thailand and Hong Kong', Food. Cosmet. Tox., Vol. 10, No. 1, pp.61-69. 
Shephard, G.S. (2008a) 'Determination of mycotoxins in human foods', Chem. Soc. Rev., Vol. 37, No. 11, pp.2468-2477.

Shephard, G.S. (2008b) 'Risk assessment of aflatoxins in food in Africa: food additive contaminant part A', Chem. Anal Cont. Expo Risk Assess., Vol. 25, No. 10, pp.1246-1256.

Sibanda, L., Marovatsanga, L.T. and Pestka, J.J. (1997) 'Review of mycotoxin work in sub-Saharan Africa', Food Control, Vol. 8, No. 647, pp.21-29.

Shier, W.T., Abbas, H.K., Wearer, M.A. and Horn, B.W. (2005) 'The case for monitoring Aspergillus flavus aflatoxinogenicity for food safety as asses countries', in Abbas, H.K. (Ed.): Aflatoxin and Food Safety, pp.291-311, CRC Press, Boka Raton.

Soares, L.M. and Rodriguez-Amaya, D.B. (1989) 'Survey of aflatoxins, ochratoxin A, zearalenone, and sterigmatocystin in some Brazilian foods by using multi-toxin thin-layer chromatographic method', J. Ass. Off. Anal. Chem., Vol. 72, No. 1, pp.22-26.

Sokolovic, M., Garaj-Vrhovac, V. and Mpraga, V. (2008) 'T-2 toxin: incidence and toxicity in poultry', Arh Hig Rada Tok., Vol. 59, No. 11, pp.43-52.

Sorensen, J.L., Aveskamp, M.M., Thrane, U. and Andersen, B. (2010) 'Polyphasic characterization of Phoma pomorum isolated from Danish maize', Int. J. Food Micro., Vol. 136, No. 3, pp.310-317.

Steinkraus, K.H. (1997) 'Classification of fermented foods: worldwide review of household fermentation technique', Food Cont., Vol. 8, Nos. 5-6, pp.311-317.

Stevens, A.J., Saunders, C.N., Spence, J.B. and Newham, A.G. (1960) 'Investigation into disease of turkey poults', Veterinary Records, Vol. 75, pp.627-628.

Steyn, P.S. and Rabie, C.J. (1976) 'Characterization of magnesium and calcium tenuazonate from Phoma sorghina', Phyt., Vol. 15, No. 12, pp.1977-1979.

Sun, X-M., Zhang, X-H., Wang, H-Y., Cao, W-J., Yan, X., Zuo, L-F., Wang, J-L. and Wang, F-R. (2002) 'Effects of sterigmatocystin, deoxynivalenol and aflatoxin g1on apoptosis of human peripheral blood lymphocytes in vitro', Biomedical And Environmental Sciences, Vol. 15, pp.145-152.

Tewe, O.O. and Kasali, O.B. (1986) 'Effect of cassava peel processing on the performance, nutrient utilization and physiopathology of the African giant rat (Cricetomys gambianus Waterhouse)', Trop. agr. (Trinidad), Vol. 63, No. 2, pp.125-128.

Ugwu, B.O. and Ay, P. (1992) Seasonality of Cassava Processing in Africa, COSCA Working Paper No. 9, Collaborative Study of Cassava in Africa, International Institute of Tropical Agriculture, Ibadan, Nigeria.

UNCTAD (2012) CNUCED Fiche Produit: Manioc [online] http://www.unctad.info/fr/Infocomm/Produits-AAACP/FICHE-PRODUIT-Manioc/) (accessed March 2013).

Wagacha, J.M. and Muthomi, J.W. (2008) 'Mycotoxin problem in Africa: current status, implications to food safety and health and possible management strategies', Int. J. Food Micro., Vol. 124, No. 1, pp.1-12.

Wareing, P.W., Westby, A., Gibbs, J.A., Allotey, L.T. and Halm, M. (2001) 'Consumer preferences and fungal and mycotoxin contamination of dried cassava products from Ghana', Int. J. Food Sci. Tech., Vol. 36, No. 1, pp.1-10.

Westby, A. (1991) 'Importance of fermentation in cassava processing', Proceedings of the Ninth Symposium of the International Society for Tropical Root Crops, Accra, Ghana, 20-26 October.

Westby, A. (2002) 'Cassava utilisation, storage and small-scale processing', in Hillocks, R., Tresh, J. and Bellotti, A. (Eds.): Cassava: Biology, Production and Utilization, pp.281-300, CABI Publishing, Wallingford, UK.

Westby, A. and Twiddy, D.R. (Eds.) (1991) 'Role of microorganisms in the reduction of cyanide during traditional processing of African cassava products', International Foundation for Science (IFS) Proceedings. Workshop on Traditional African Foods: Quality and Nutrition, Stockholm, Sweden, Vols. 25-29, pp.127-131. 
Westby, A. Ikwning, E.P., Gibbs, J.A. and Dallin, S.M. (1995a) 'Formation of aflatoxins by Aspergillus flavus and A. parasiticus isolates from cassava products: transformation Alimentaire du Manioc', Agbor Egbe, T., Brauman, A., Griffon, D. and Treche, S. (Eds.): ORSTOM.

Westby, A., Wareing, P., Gibbs, J. and Dallin, S. (1995b) 'Formation of aflatoxins by Aspergillus flavus and A. parasiticus isolates from cassava products', in Agbor Egbe, T., Brauman, A., Griffon, D. and Treche, S. (Eds.): Transformation Alimentaire du Manioc, pp.375-381, Orstom, Paris.

Westby, A., Wareing, P.W. and Gibbs, J.A. (1994) 'Ability of cassava products to support mycotoxin formation', Paper and poster presented at the 10th Triennal Symposium of the International Society for Tropical Root Crops, Brazil, November 1994.

Wicklow, D.T. (1994) 'Preharvest origins of toxigenic fungi in stored grain', in Highley, E., Wright, E.J., Banks, H.J. and Champ, B.R., (Eds.): Stored Product Protection: Proceedings of the Sixth International Working Conference on Stored-Product Protection, CAB International, Wallingford, UK, pp.1075-1081.

Wild, C.P. (2007) 'Aflatoxin exposure in developing countries: the critical interface of agriculture and health', Food Nutr. Bull., Vol. 28, No. 2, Suppl., pp.372-380.

Wild, C.P. and Gong, Y.Y. (2010) 'Mycotoxins and human disease: a largely ignored global health issue', Carc., Vol. 31, No. 1, pp.71-82.

Williams, J.H., Phillips, T.D., Jolly, P.E., Stiles, J.K., Jolly, C.M. and Aggarwal, D. (2004) 'Human aflatoxicosis in developing countries: a review of toxicology, exposure, potential health consequences, and interventions', Amer. J. Clin. Nutr., Vol. 80, No. 5, pp.1106-1122.

$\mathrm{Wu}, \mathrm{F}$. (2004) 'Mycotoxin risk assessment for the purpose of setting international regulatory standards', Env. Sci. Tech., Vol. 38, No. 15, pp.4049-4055.

Zhou, B. and Qiang, S. (2008) 'Environmental, genetic and cellular toxicity of tenuazonic acid isolated from Alternaira alternate', Afr. J. Bio. Vol. 7, No. 8, pp.1151-1156. 